\title{
Bio-chemostratigraphy of the Barremian-Aptian shallow-water carbonates of the southern Apennines (Italy): pinpointing the OAE1a in a Tethyan carbonate platform
}

\author{
M. Di Lucia ${ }^{1}$, A. Trecalli ${ }^{2}$, M. Mutti ${ }^{1}$, and M. Parente ${ }^{2}$ \\ ${ }^{1}$ Institut für Erd- und Umweltwissenschaften, Universität Potsdam, Karl-Liebknecht-Str. 24-25, \\ 14476 Potsdam Golm, Germany \\ ${ }^{2}$ Dipartimento di Scienze della Terra, Università degli Studi di Napoli "Federico II", Largo San Marcellino 10, \\ 80138 Napoli, Italy \\ Correspondence to: M. Di Lucia (dilucia@geo.uni-potsdam.de)
}

Received: 2 September 2011 - Published in Solid Earth Discuss.: 14 September 2011

Revised: 20 December 2011 - Accepted: 20 December 2011 - Published: 27 January 2012

\begin{abstract}
Low biostratigraphic resolution and lack of chronostratigraphic calibration hinder precise correlations between platform carbonates and coeval deep-water successions. These are the main obstacle when studying the record of Mesozoic oceanic anoxic events in carbonate platforms. In this paper carbon and strontium isotope stratigraphy are used to produce the first chronostratigraphic calibration of the Barremian-Aptian biostratigraphy of the Apenninic carbonate platform of southern Italy. According to this calibration, the segment of decreasing $\delta^{13} \mathrm{C}$ values, leading to the negative peak that is generally taken as the onset of the Selli event, starts a few metres above the last occurrence of Palorbitolina lenticularis and Voloshinoides murgensis. The following rise of $\delta^{13} \mathrm{C}$ values, corresponding to the interval of enhanced accumulation of organic matter in deep-water sections, ends just below the first acme of Salpingoporella dinarica, which roughly corresponds to the segment of peak $\delta^{13} \mathrm{C}$ values. The whole carbon isotope excursion associated with the oceanic anoxic event 1a is bracketed in the Apenninic carbonate platform between the last occurrence of Voloshinoides murgensis and the "Orbitolina level", characterized by the association of Mesorbitolina parva and Mesorbitolina texana. Since these bioevents have been widely recognized beyond the Apenninic platform, the calibration presented in this paper can be used to pinpoint the interval corresponding to the Early Aptian oceanic anoxic event in other carbonate platforms of central and southern Tethys. This calibration will be particularly useful to interpret the record of the Selli event in carbonate platform sections for which a reliable carbon isotope stratigraphy is not available.
\end{abstract}

\section{Introduction}

The Early Aptian oceanic anoxic event 1a (OAE1a), also known as the Selli event, was a time of severe perturbation of the global carbon cycle. The most popular scenario holds that intense volcanism, associated with the emplacement of the Ontong-Java large igneous province, forced the rapid increase of atmospheric $p \mathrm{CO}_{2}$ that triggered a cascade of palaeoenvironmental changes (Larson and Erba, 1999; Méhay et al., 2009; Tejada et al., 2009). The deposition on a global scale of organic-rich marine sediments, the demise of the northern Tethyan carbonate platform and a biocalcification crisis recorded by calcareous nannoplankton are among the most significant testimonies left in the geological record (Arthur et al., 1990; Wissler et al., 2003; Weissert and Erba, 2004; Erba et al., 2010). Most of what is known about the response of the Earth System to the perturbations associated with the Selli event comes from the vast amount of data recovered during the last decades from hemipelagic and pelagic sedimentary successions deposited in epicontinental and oceanic basins. Much less is known of the response of tropical carbonate platforms, which potentially contain a very valuable archive of environmental change (Hallock, 2001; Strasser et al., 2011).

While the long-lived Urgonian platform was drowned shortly before the onset of the OAE1a (Wissler et al., 2003; Föllmi et al., 2006; Huck et al., 2011), some carbonate platforms in the central and southern Tethys were able to continue growing in shallow water. These resilient platforms preserve the record of palaeoecologic disturbance of tropical 


\begin{tabular}{|c|c|c|c|c|c|c|}
\hline Age & \multicolumn{2}{|c|}{ Apenninic carbonate platform } & \multicolumn{3}{|c|}{ Adriatic carbonate platform } & N-Israel carbonate platform \\
\hline \multirow{4}{*}{ 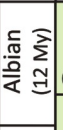 } & \multirow{3}{*}{$\begin{array}{c}\text { Peneroplis parvus } \\
\text { taxon-range zone } \\
\text { (upper boundary: earliest Cenomanian) }\end{array}$} & \multirow{4}{*}{$\begin{array}{c}\text { Ostracoda/Miliolidae } \\
\text { assemblage zone } \\
\text { (upper boundary: middle Cenomanian) }\end{array}$} & \multirow[b]{2}{*}{ V. dercourti taxon-range zone } & \multicolumn{2}{|c|}{ N.convexa taxon-range zone } & \\
\hline & & & & \multicolumn{2}{|c|}{ V. dercourti partial-range zone } & \\
\hline & & & \multirow{2}{*}{$\begin{array}{l}\text { M.texana/V. dercourti } \\
\text { Interval zone }\end{array}$} & \multirow{2}{*}{\multicolumn{2}{|c|}{$\begin{array}{c}\text { Mesorbitolina subconcava } \\
\text { taxon-range zone }\end{array}$}} & \\
\hline & \multirow{2}{*}{$\begin{array}{c}\text { Sabaudia minuta } \\
\text { interval zone }\end{array}$} & & & & & \\
\hline \multirow{4}{*}{ 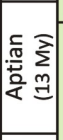 } & & Archaeoalveol. reicheli taxon-range zone & \multirow{2}{*}{$\begin{array}{c}\text { Salpingoporella dinarica } \\
\text { Abundance zone }\end{array}$} & \multirow{2}{*}{\multicolumn{2}{|c|}{$\begin{array}{l}\text { Mesorbitolina parva lineage zone } \\
\text { Mesorbitolina texana lineage zone }\end{array}$}} & M. texana/M. parva interval zone \\
\hline & \multirow{5}{*}{$\begin{array}{l}\text { Salpingoporella } \\
\text { dinarica } \\
\text { taxon-range zone }\end{array}$} & \multirow{3}{*}{$\begin{array}{l}\text { Salpingoporella dinarica } \\
\text { taxon-range zone }\end{array}$} & & & & Mesorbitolina parva interval zone \\
\hline & & & Bacinella irregularis & \multirow{3}{*}{$\begin{array}{c}\text { Palorbitolina } \\
\text { lenticularis } \\
\text { superzone }\end{array}$} & P. wienandsi lineage zone & P. cormyi/M.lotzei interval zone \\
\hline & & & assemblage zone & & P. cormyi lineage zone & Palorbitolina lenticularis interval zone \\
\hline \multirow{3}{*}{ 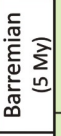 } & & \multirow{6}{*}{$\begin{array}{l}\text { ?Cuneolina scarsellai/ } \\
\text { Cuneolina camposauri } \\
\text { assemblage zone }\end{array}$} & Salpingoporella melitael & & $\begin{array}{c}R . \text { giganteus/P. lenticularis } \\
\text { assemblage zone }\end{array}$ & P. lenticularis-C. decipiens interval zone \\
\hline & & & $\begin{array}{l}\text { Salpingoporella muhelbergii } \\
\text { Interval zone }\end{array}$ & C. capue & $\begin{array}{l}\text { ensis-P. lenticularis } \\
\text { interval zone }\end{array}$ & \\
\hline & \multirow{2}{*}{$\begin{array}{l}\text { Campanellula capuensis } \\
\text { taxon-range zone }\end{array}$} & & & & C. capuensis & \\
\hline \multirow{4}{*}{ 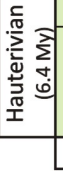 } & & & \multirow{3}{*}{$\begin{array}{l}\text { Clypeina? solkani } \\
\text { Abundance zone }\end{array}$} & & xon-range zone & \\
\hline & \multirow{2}{*}{$\begin{array}{l}\text { Cuneolina laurentii } \\
\text { interval zone } \\
\text { (lower boundary: latest Valanginian) }\end{array}$} & & & \multirow{2}{*}{\multicolumn{2}{|c|}{$\begin{array}{l}\text { V. camposaurii-C. capuensis } \\
\text { interval zone }\end{array}$}} & \\
\hline & & & & & & \\
\hline & De Castro (1991) & Chiocchini et al. (2008) & Husinec and Sokač (2006) & & Velić (2007) & Bachmann and Hirsch (2006) \\
\hline
\end{tabular}

Fig. 1. Barremian-Aptian biostratigraphy of central-southern Tethyan carbonate platforms. These schemes suffer of low resolution and poorly constrained chronostratigraphic calibration.

neritic ecosystems (Immenhauser et al., 2005; Huck et al., 2010). In order to unlock this archive, the first step is to bracket the segments corresponding to OAEs, but this is not a trivial task in shallow-water carbonate successions. Black shales are notably absent in carbonate platforms, and also the occurrence of dysoxic facies can be misleading because it is more often the result of locally restricted circulation than of global ocean anoxia (Davey and Jenkyns, 1999). Biostratigraphy may not always offer a complete solution either. The onset of the OAE1a has been dated to the lower part of the Deshayesites deshayesi ammonite zone (Föllmi et al., 2007). However, ammonites are very rarely found in shallow-water carbonate platforms and there is, at present, no precise calibration of shallow-water biostratigraphic schemes with the ammonite standard zonation and with the geological time scale. A recent review has highlighted how low biostratigraphic resolution and lack of precise chronostratigraphic calibration hinders a full appraisal of the response of carbonate platforms to climate and ocean chemistry changes during the Aptian (Skelton and Gili, 2011).

Biozonations of central and southern Tethyan Early Cretaceous carbonate platforms are based on benthic foraminifers and calcareous algae (De Castro, 1991; Simmons, 1994; Husinec and Sokač, 2006; Velić, 2007; Chiocchini et al., 2008). Resolution is rather low (3 biozones over $18 \mathrm{My}$, adopting the Geological Time Scale of Gradstein et al., 2004; hereinafter GTS2004) but can be considerably improved with orbitolinid foraminifers (Fig. 1).

The chronostratigraphic scale tied to these shallow water biostratigraphic schemes conveys the impression that longdistance precise correlation between different carbonate platforms, as well as correlation with coeval deep-water facies, can be easily attained. However, a more in-depth appraisal of the papers on the biostratigraphy of Tethyan carbonate platforms reveals that the chronostratigraphic calibration of the biozones is admittedly tentative (De Castro, 1991; Chiocchini et al., 2008) or entirely based on the age of orbitolinid foraminifera as established in the Urgonian Platforms of the Northern Tethyan margin (Bachmann and Hirsch, 2006; Velić, 2007).

In the absence of black shales and of a reliable biostratigraphic criterion, the identification of segments corresponding to the Selli event in the resilient carbonate platforms of the central and southern Tethys is generally based on carbon isotope stratigraphy. However, the pristine carbon isotope signal of the open ocean can be modified by local palaeoceanographic processes and later overprinted to a considerable extent by diagenesis (see Immenhauser et al., 2008, for a recent review). As a result, many published carbon isotope profiles of Lower Cretaceous shallow-water carbonate successions are markedly different from, and very difficult to correlate with, basinal reference curves (D'Argenio et al., 2004; Huck et al., 2010; Tešović et al., 2011). Carbon isotope stratigraphy has been already applied to several Barremian-Aptian carbonate successions of the Apenninic carbonate platform (ACP) of Southern Italy (Ferreri et al., 1997; D’Argenio et al., 2004; Wissler et al., 2004; Di Lucia and Parente, 2008; Di Lucia, 2009). The first attempt to use carbon isotope stratigraphy for correlation with well dated basinal sections and for bracketing the interval corresponding to the OAE1a, was made by Ferreri et al. (1997). A higher resolution $\delta^{13} \mathrm{C}$ curve for the same section investigated by Ferreri et al. (1997), Mt. Raggeto, was produced by Wissler et al. (2004). Both these papers incorporate a high resolution cyclostratigraphic framework, but provide very few biostratigraphic data.

In this paper we present the re-interpretation of the carbon isotope stratigraphy of three Barremian-Aptian successions 


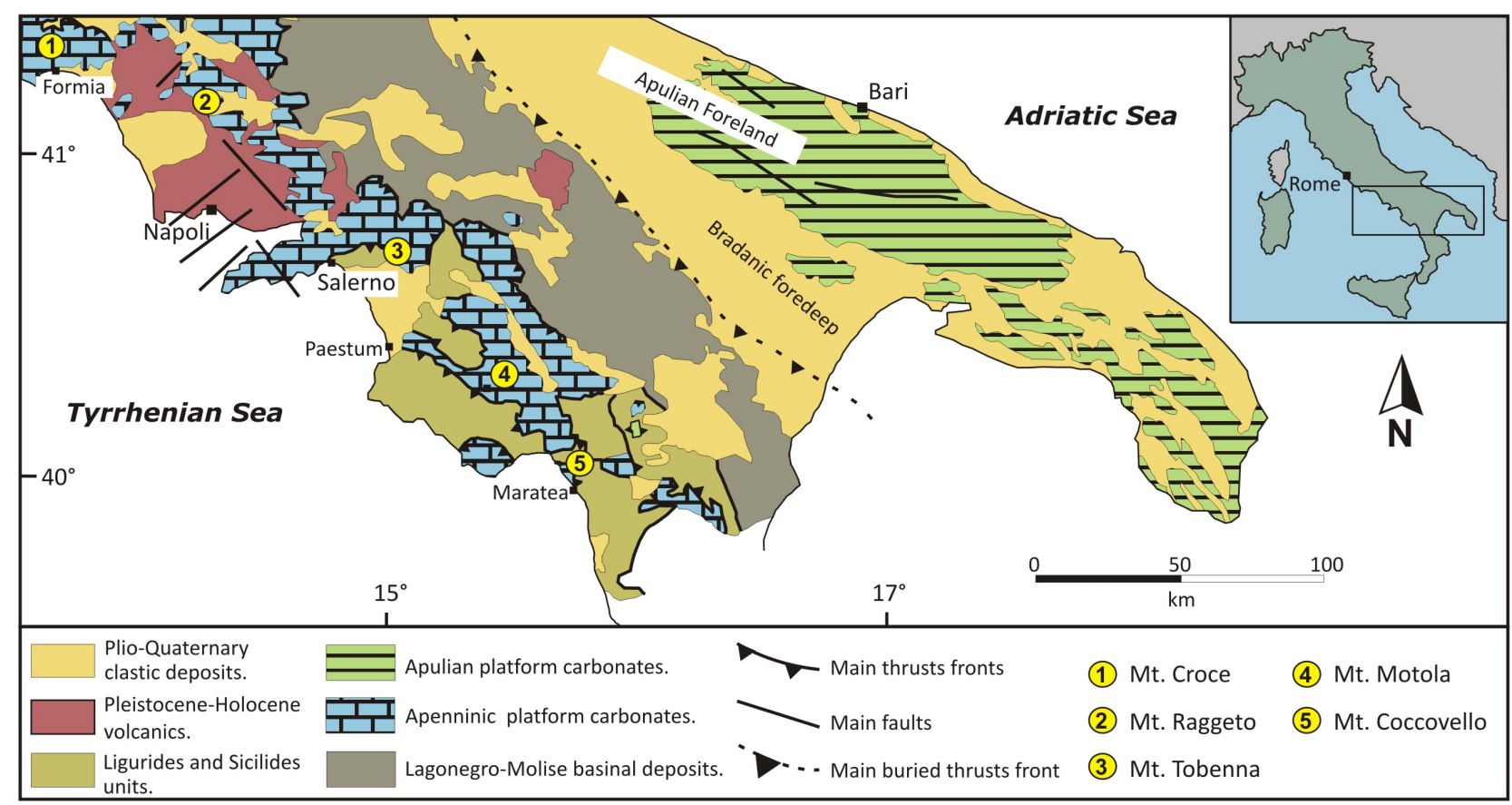

Fig. 2. Schematic geological map of the central-southern Apennines, with location of the studied sections (modified from Bonardi et al., 1988).

formerly studied by Di Lucia and Parente (2008) and Di Lucia (2009) and new biostratigraphic and chemostratigraphic data on two key sections formerly studied by Wissler et al. (2004) and D'Argenio et al. (2004): Mt. Raggeto and Mt. Tobenna. In particular, the correlation with the most complete Mt. Raggeto section reveals previously undisclosed gaps in the other sections. This highlights the difficulties of applying carbon isotope stratigraphy to inherently incomplete carbonate platform sections.

The most significant result of the present study is the proposal of chemostratigraphically constrained biostratigraphic criteria for the individuation of the time-equivalent of the Selli event and of the Barremian-Aptian boundary in central and southern Tethyan carbonate platforms. Moreover, we propose a chronostratigraphic calibration of some important biostratigraphic events that are widely used in the BarremianAptian biozonations of central and southern Tethyan carbonate platforms.

\section{Geological setting}

The shallow-water carbonates that are widely exposed in southern Italy (Fig. 2) are the relics of carbonate banks that developed during the Mesozoic on the passive margin of Adria, a promontory of the African Plate (Bosellini, 2002). Starting from the Middle Triassic, the continental rifting individuated two wide platforms, the Apenninic platform and the Apulian platform, separated by a deep basin (the Lagonegro Basin). Shallow-water carbonate sedimentation persisted almost to the end of the Cretaceous, when the platforms emerged, and was locally re-established during the Palaeogene and the Early Miocene, to be eventually terminated by drowning and siliciclastic deep-water deposits. The total thickness of the Mesozoic succession of the Apenninic carbonate platform can be estimated to about $4-5 \mathrm{~km}$ with about $1-1.2 \mathrm{~km}$ pertaining to the Cretaceous (Sartoni and Crescenti, 1962; D'Argenio and Alvarez, 1980; Frijia et al., 2005). The Upper Triassic to Lower Cretaceous limestones and dolomites are generally referred to as flat-topped, Bahamian-type tropical carbonate platforms, dominated by chloralgal and chlorozoan associations (D'Argenio et al., 1975) whereas the depositional system of the Upper Cretaceous rudist limestones has been interpreted as a ramp-like open shelf, dominated by foramol-type assemblages (Carannante et al., 1997).

\section{Materials and methods}

\subsection{Sedimentology and biostratigraphy}

Five shallow-water carbonate successions have been selected for this study: Mt. Croce (north of Formia, Lazio), Mt. Raggeto (northwest of Caserta, Campania), Mt. Tobenna (east of Salerno, Campania), Mt. Motola (south of Salerno, Campania) and Mt. Coccovello (north of Maratea, Basilicata) (Fig. 2). The studied sections were logged in the field at decimetre to metre scale, depending on the outcrop quality, 
and sampled with an average resolution of about one sample per metre. The preliminary field description of textural components, sedimentary structures and fossil content was subsequently integrated with the sedimentological and micropalaeontological study of about 520 double-polished thin sections.

\subsection{Carbon and oxygen isotopes}

Six hundred samples were analysed for the ${ }^{13} \mathrm{C} /{ }^{12} \mathrm{C}$ and ${ }^{18} \mathrm{O} /{ }^{16} \mathrm{O}$ ratios. Mudstones were used as a first choice and the micritic matrix of wackestones and floatstones as a second choice. About $2 \mathrm{mg}$ of powder was obtained from each sample by micro-drilling a polished slab under a binocular microscope with a $0.5 \mathrm{~mm}$ or $0.8 \mathrm{~mm}$ Tungsten bit. The analyses were performed at the Isotopen-labor of the Institut für Geologie, Mineralogie und Geophysik at the Ruhr University (Bochum, Germany). Approximately $0.5 \mathrm{mg}$ of sample powder was heated for $18 \mathrm{hrs}$ at $105^{\circ} \mathrm{C}$. Samples were reacted online by individual acidic $\left(\mathrm{H}_{3} \mathrm{PO}_{4}\right)$ addition with a Finnigan Gas Bench II. Stable isotope ratios were measured with a Finnigan Delta $\mathrm{S}$ mass spectrometer. The results are reported in $\% \circ$ in the conventional $\delta$ notation with reference to the Vienna Pee Dee Belemnite (VPDB) standard. The precision $(1 \sigma)$ monitored by repeated analyses of international and laboratory standards, is $\pm 0.09 \%$ for carbon and $\pm 0.13 \%$ o for oxygen isotopes. Replicate measurements show reproducibility in the range of $\pm 0.1 \%$ for $\delta^{13} \mathrm{C}$ and $\pm 0.2 \%$ o for $\delta^{18} \mathrm{O}$.

A three-points moving average smoothing has been applied to the $\delta^{13} \mathrm{C}$ and $\delta^{18} \mathrm{O}$ profiles in order to filter out high frequency (metre scale) fluctuations and to facilitate visual correlation between the studied successions and the reference curves.

\subsection{Strontium isotopes}

Thirteen fragments of requienid shells from four different stratigraphic levels, plus the micritic matrix of the same levels were analysed for the ${ }^{87} \mathrm{Sr} /{ }^{86} \mathrm{Sr}$ isotope ratio. The best preserved shells were selected in the field using as first guidance colour preservation (yellowish to dark brown or dark grey) and preliminary analysis of shell microstructure with the hand lens. The samples were then passed through a complete procedure of diagenetic screening, involving standard petrography (optical microscopy, cathodoluminescence and SEM) and analysis of minor and trace element concentration (see Frijia and Parente, 2008, for a full description of the screening procedure and for analytical details). The numerical ages of the samples were derived from the look-up table of McArthur et al. (2001, version 4: 08/04), which is tied to the GTS2004. Minimum and maximum ages were obtained by combining the statistical uncertainty ( $2 \mathrm{~s}$. e.) of the mean values of the Sr-isotope ratios of the samples with the uncertainty of the seawater curve.

\section{Results}

\subsection{Lithostratigraphy, lithofacies associations and palaeoenvironmental interpretation}

From a lithostratigraphic point of view, the five studied sections belong entirely to the "Calcari con Requienie e Gasteropodi" Formation (Requienid and Gastropod limestones Formation). Eight Lithofacies Associations (LA) (Table 1) have been identified on the basis of texture, components (with special emphasis on fossil assemblages) and sedimentary structures. The main skeletal components are mollusks (gastropods, ostreids and requienid rudists), benthic foraminifers and green algae, with additional contribution from microbial nodules and crusts. Non-skeletal grains are mainly represented by peloids and intraclasts. The nomenclature of the LA conforms to that adopted by previous Authors for the Lower Cretaceous carbonates of the Apenninic carbonate platform and of other carbonate platforms of the central-southern Tethyan domain (Raspini, 2001; Pittet et al., 2002; Hillgärtner et al., 2003; D'Argenio et al., 2004; Bachmann and Hirsch, 2006). The described lithofacies represent a full range of sub-environments, from supratidal marsh with ponds, to tidal flat to subtidal restricted to open lagoon (Fig. 3). A synoptic description of LA is given in Table 1. All the studied successions can be generally ascribed to an inner platform setting. The Mt. Raggeto and the Mt. Croce sections show more open marine facies, organized mainly in subtidal and, subordinately, in peritidal metric cycles. More restricted facies occur at Mt. Tobenna, Mt. Motola and Mt. Coccovello, where peritidal cycles dominate the successions and subaerial exposure surfaces are more prominent and frequent.

Greenish marly levels are a very typical feature of the Mt. Tobenna section (see also Raspini, 1998, 2011). They occur as mm-thick partings between calcareous beds or as $\mathrm{cm}$ to $\mathrm{dm}$-thick laterally discontinuous levels. The thickest levels often contain nodules of mudstones-wackestones with charophytes and ostracods (LA1). These marly levels document phases of subaerial exposure of the platform top. In all the other sections mm-thick recessive marly partings are often observed while the thickest marly levels seemingly correspond to poorly exposed intervals covered by grass and shrubs.

\subsection{Biostratigraphy}

The following species of benthic foraminifers and calcareous algae have been used in this paper for the biostratigraphic subdivision and correlation of the studied successions (Figs. 4, 5)

- Praechrysalidina infracretacea LUPERTO SINNI, 1979

- Salpingoporella dinarica RADOIČIĆ, 1959

- Palorbitolina lenticularis (BLUMENBACH, 1805) 
Table 1. Lithofacies description and palaeoenvironmental interpretation

\begin{tabular}{|c|c|c|c|c|}
\hline $\begin{array}{l}\text { Lithofacies } \\
\text { associations (LA) }\end{array}$ & Texture & $\begin{array}{l}\text { Skeletal and non-skeletal } \\
\text { components }\end{array}$ & $\begin{array}{l}\text { Sedimentary and } \\
\text { diagenetic features }\end{array}$ & $\begin{array}{l}\text { Environmental } \\
\text { interpretation }\end{array}$ \\
\hline $\begin{array}{l}\text { Chara-Ostracodal } \\
\text { limestones (LA 1) }\end{array}$ & $\begin{array}{l}\text { Mudstone/ } \\
\text { Wackestone }\end{array}$ & $\begin{array}{l}\text { Thin shelled ostracods (a), characean oogonia (c) and } \\
\text { stems (r), small and thin shelled gastropods (r). }\end{array}$ & $\begin{array}{l}\text { Dissolution cavities with } \\
\text { vadose silt and/or sparry } \\
\text { calcite infilling. }\end{array}$ & $\begin{array}{l}\text { Ephemeral supratidal } \\
\text { ponds }\end{array}$ \\
\hline $\begin{array}{l}\text { Fenestral and/or } \\
\text { Microbialitic } \\
\text { limestones (LA 2) }\end{array}$ & $\begin{array}{l}\text { Mudstone/ } \\
\text { Wackestone }\end{array}$ & $\begin{array}{l}\text { Ostracods (c), small miliolids (c), } \\
\text { thin-shelled gastropods (r), Thaumatoporella } \\
\text { (r). }\end{array}$ & $\begin{array}{l}\text { Fenestrae, birdseyes, } \\
\text { dissolution cavities (with } \\
\text { vadose silt, sparry calcite } \\
\text { or marly infilling), mud- } \\
\text { cracks and black peb- } \\
\text { bles. }\end{array}$ & $\begin{array}{l}\text { Tidal flat and/or very } \\
\text { restricted lagoon }\end{array}$ \\
\hline $\begin{array}{l}\text { Mili-Ostr-Algal } \\
\text { limestones (LA 3) }\end{array}$ & $\begin{array}{l}\text { Mudstone/ } \\
\text { Wackestone }\end{array}$ & $\begin{array}{l}\text { Ostracods (a), small miliolids (a), green algae (c), thin- } \\
\text { shelled gastropods (r), } \\
\text { textularids (c). }\end{array}$ & $\begin{array}{l}\text { Dissolution cavities with } \\
\text { vadose silt and/or sparry } \\
\text { calcite infilling. }\end{array}$ & $\begin{array}{l}\text { Intertidal to shallow } \\
\text { subtidal } \\
\text { protected lagoon }\end{array}$ \\
\hline $\begin{array}{l}\text { S. dinarica } \\
\text { limestones (LA 4) }\end{array}$ & $\begin{array}{l}\text { Wackestone/ } \\
\text { Packstone }\end{array}$ & $\begin{array}{l}\text { S. dinarica (va), cuneolinids (r), nezzazzatids (r), os- } \\
\text { tracods }(r) \text {, peloids }(r) \text {. }\end{array}$ & $\begin{array}{l}\text { S. dinarica sometimes } \\
\text { crushed and isoriented } \\
\text { parallel to bedding. }\end{array}$ & $\begin{array}{l}\text { Shallow subtidal pro- } \\
\text { tected lagoon }\end{array}$ \\
\hline $\begin{array}{l}\text { Bio-Peloidal } \\
\text { limestones (LA 5) }\end{array}$ & $\begin{array}{l}\text { Packstone/ } \\
\text { Grainstone }\end{array}$ & $\begin{array}{l}\text { Benthic forams and green algae (a), molluskan shell } \\
\text { fragments and ostracods (r), peloids and intraclasts (a), } \\
\text { ooids, oncoids and aggregate grains (r). }\end{array}$ & $\begin{array}{l}\text { Parallel lamination (r), } \\
\text { gradation (r). }\end{array}$ & $\begin{array}{l}\text { Shallow subtidal sand } \\
\text { bars }\end{array}$ \\
\hline $\begin{array}{l}\text { For-Algal } \\
\text { limestones (LA 6) }\end{array}$ & $\begin{array}{l}\text { Wackestone/ } \\
\text { Packstone }\end{array}$ & $\begin{array}{l}\text { Benthic forams (a), green algae (c), ostracods } \\
\text { (r), molluskan and echinoid shell fragments (c), } \\
\text { Lithocodium/Bacinella nodules } \\
\text { (c to a) and faecal pellets (r). }\end{array}$ & Bioturbation. & Subtidal open lagoon \\
\hline $\begin{array}{l}\text { Molluskan } \\
\text { limestones (LA 7) }\end{array}$ & Floatstone & $\begin{array}{l}\text { Requienid and/or gastropods (a). Matrix } \\
\text { of bio-peloidal-intraclastic } \\
\text { wackestone/packstone/ grainstone, with } \\
\text { benthic forams (c), green algae (c), } \\
\text { Lithocodium/Bacinella (r) and faecal pellets (r). }\end{array}$ & $\begin{array}{l}\text { Bioturbation, Bioerosion } \\
\text { of molluskan shells. }\end{array}$ & Subtidal open lagoon \\
\hline \multirow{2}{*}{$\begin{array}{l}\text { Palorbitolina } \\
\text { limestones and } \\
\text { Orbitolinid/codiaceans } \\
\text { marls and } \\
\text { limestones } \\
\text { (LA 8) }\end{array}$} & $\begin{array}{l}\text { Mudstone/ } \\
\text { Wackestone }\end{array}$ & $\begin{array}{l}\text { Orbitolinids (P. lenticularis) (c to a), miliolids and } \\
\text { textularids (c), Lithocodium/Bacinella nodules (c), } \\
\text { molluskan and echinoid shell fragments (c), sponge } \\
\text { spicules (a), oncoids, intraclasts and peloids (r). }\end{array}$ & $\begin{array}{l}\text { Bioturbation, stylonodu- } \\
\text { lar structures. }\end{array}$ & Deep open lagoon \\
\hline & Packstone & $\begin{array}{l}\text { Orbitolinids (va) (Mesorbitolina. parva, M. texana) } \\
\text { and codiaceans (va) (B. hochstetteri moncharmontiae), } \\
\text { dasycladaceans (r), textularids (r) and echinoid shell } \\
\text { fragments (c), micritic intraclasts (c). }\end{array}$ & $\begin{array}{l}\text { Bioturbation,micritization } \\
\text { of orbitolinid shells, } \\
\text { stylonodular structures. }\end{array}$ & \\
\hline
\end{tabular}

$\mathrm{va}=$ very abundant $; \mathrm{a}=$ abundant $; \mathrm{c}=$ common $; \mathrm{r}=$ rare

- Voloshinoides murgensis LUPERTO SINNI and MASSE, 1993

- Debarina hahounerensis FOURCADE, RAOULT and VILA, 1972

- Mesorbitolina parva (DOUGLASS, 1960)

- Mesorbitolina texana (ROEMER, 1849)

- Archaeoalveolina reicheli (DE CASTRO, 1966)

- Cuneolina parva HENSON, 1948

The first and last occurrences (FO and LO) of these species are the basis of the most widely used biostratigraphic schemes for the central and southern Tethyan domain and their homotaxial order has been documented from the Apenninic, to the Adriatic-Dinaric to the Gavrovo-Tripolitza to the north African and Middle East carbonate Platforms (Chiocchini et al., 1994, 2008; Simmons, 1994; Husinec and Sokač, 2006; Velić, 2007; Tešović et al., 2011).

The correlation of the studied successions is based in particular on the following biostratigraphic markers, which can also be easily recognized in the field:

(1) The "Archaeoalveolina reicheli level", represented by few metres of wackestone-packstones with abundant A. reicheli.

(2) The "Orbitolina level", a 40 to $170 \mathrm{~cm}$-thick composite bed consisting of marls and marly limestones full of flat 


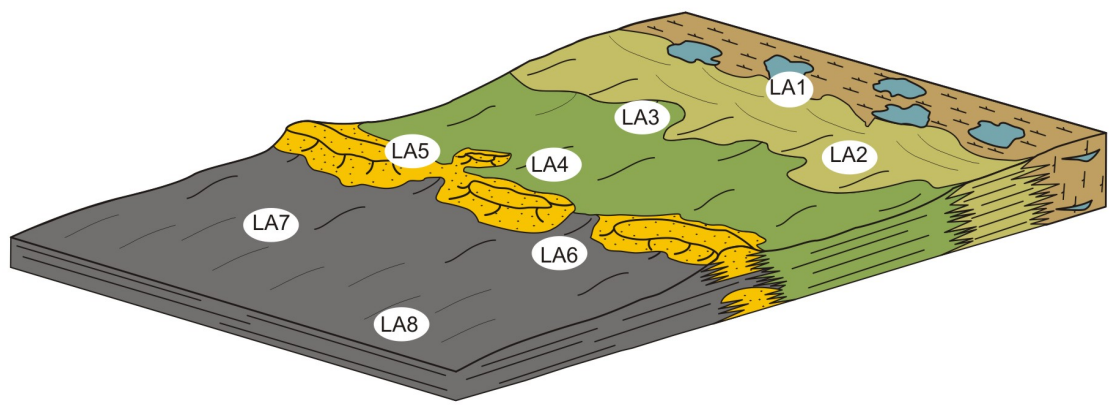

ॠते Supratidal with ponds

$\square$ Tidal flat

Protected lagoon

$\therefore \because$ Intertidal to shallow subtidal shoals

Open lagoon

Fig. 3. Schematic depositional model with facies distribution.
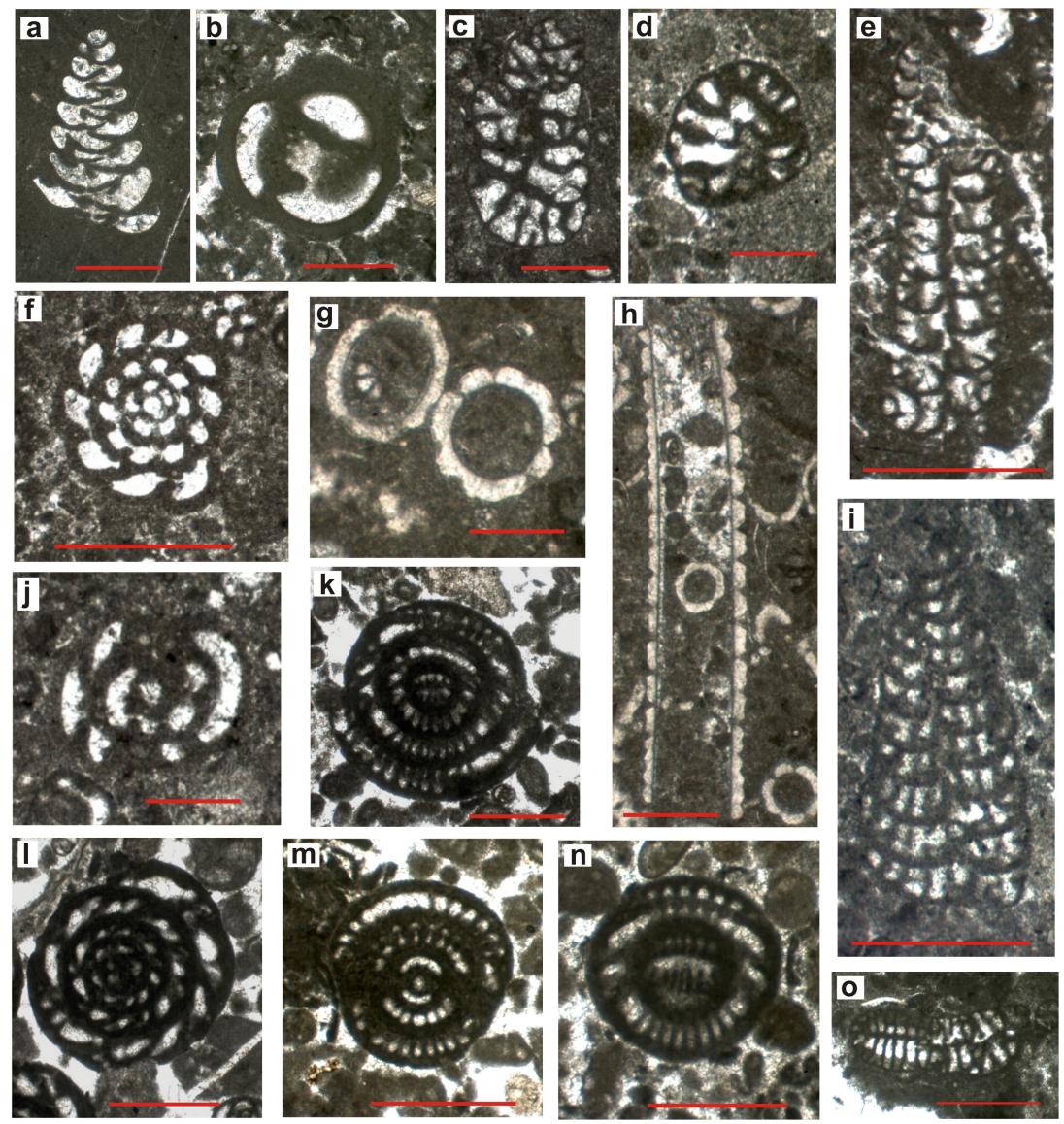

Fig. 4. (a) Praechrysalidina infracretacea, axial section (Mt. Croce, sample CR 70.5); (b) Praechrysalidina infracretacea, transversal section (Mt. Croce, CR 55.4); (c) Voloshinoides murgensis, sub-axial section (Mt. Coccovello, CO 1.8); (d) Voloshinoides murgensis, sub-transversal section (Mt. Motola, MO 89.7); (e) Cuneolina parva, axial section (Mt. Motola, MO 137.7); (f) Debarina hahounerensis, equatorial section (Mt. Coccovello, CV 79.2a); (g) Salpingoporella dinarica, transversal section (Mt. Motola, MO 103.8); (h) Salpingoporella dinarica, axial section (Mt. Motola, MO 103.8); (i) Cuneolina parva, axial section (Mt. Motola, MO 137.7); (j) Debarina hahounerensis, sub-axial section (Mt. Coccovello, CV 79.2a); (k) Archaeoalveolina reicheli, sub-axial section (Mt. Coccovello, CO 30.2); (l) Archaeoalveolina reicheli, equatorial section (Mt. Coccovello, CO 30.2); (m) Archaeoalveolina reicheli, axial section (Mt. Coccovello, CO 30.2); (n) Archaeoalveolina reicheli, tangential section (Mt. Coccovello, CO 30.2); (o) Cuneolina parva, sub-transversal section (Mt. Motola, MO 137.7). Scale bar is 500 microns for all photographs. 

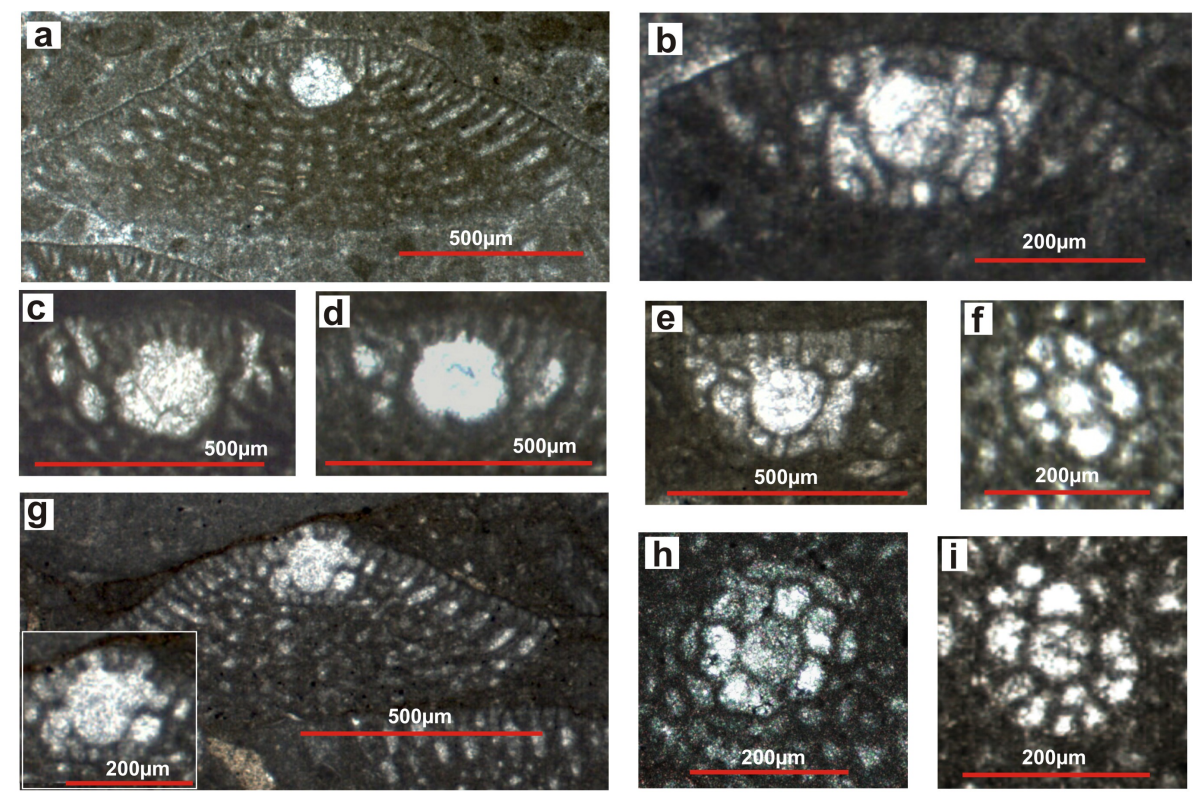

Fig. 5. (a) Palorbitolina lenticularis, axial section through the embryonic apparatus (Mt. Coccovello, sample CV 71.7); (b) Mesorbitolina texana, axial section through the embryonic apparatus; (c-d) Palorbitolina lenticularis, axial section through the embryonic apparatus (Mt. Coccovello, CV 65.4a); (e) Mesorbitolina texana, axial section through the embryonic apparatus (Mt. Coccovello, CV 77.9a); (f) Mesorbitolina texana, subtransversal section of the embryonic apparatus, slightly oblique through the subembryonic zone (Mt. Coccovello, CV 77.9a); (g) Mesorbitolina parva, axial section through the embryonic apparatus, with detail of the embryonic apparatus (Mt. Coccovello, CV 77.9a); (h) Mesorbitolina parva, transversal section through the embryonic apparatus (Mt. Tobenna, TB 8.3); (i) Mesorbitolina parva, subtransversal section of the embryonic apparatus, oblique through the subembryonic zone (Mt. Coccovello, CV 77.9a).

low-conical orbitolinids ( $M$. parva and M. texana). The top $15-20 \mathrm{~cm}$ are typically made of packstones/grainstones with orbitolinids and codiacean green algae (Boueina hochstetteri moncharmontiae DE CASTRO, 1978) (Fig. 6, 7a). In the Mt. Coccovello section there are several cm-thick levels of marls with orbitolinids within a $6 \mathrm{~m}$-thick interval of poor exposure. This interval terminates with a $15 \mathrm{~cm}$ thick bed of packstones with orbitolinids and codiacean algae.

(3) The Salpingoporella dinarica acmes, represented by two distinct m-thick intervals of packstones crowded with $S$. dinarica, occurring respectively a few metres below and above the "Orbitolina level" (Fig. 7b).

(4) The Palorbitolina limestones, represented by $10-20 \mathrm{~m}$ of wackestones with P. lenticularis, ostreids, Lithocodium/Bacinella nodules and sponge spicules.

\subsection{Stratigraphy of the studied sections}

\subsubsection{Mt. Croce}

This succession was logged on the southern side of Mt. Croce in the Aurunci Mountains, about $17 \mathrm{~km}$ northwest of Formia $\left(4^{\circ} 23^{\prime} 55^{\prime \prime} \mathrm{N}, 13^{\circ} 31^{\prime} 45^{\prime \prime} \mathrm{E}\right)$ (Fig. 2). It is $146.2 \mathrm{~m}$ thick and has been divided into four intervals (A-D) on the basis of major changes in LA at the decametre scale (Fig. 8).
Interval A $(0-45 \mathrm{~m})$ shows a regular alternation of fenestral, mili-ostr-algal and bio-peloidal limestones arranged in metric shallowing-upward (SU) cycles. In the first $20 \mathrm{~m}$ intertidal and supratidal facies prevail and subaerial exposure surfaces are well developed at the top of some SU cycles. The thickness of subtidal facies increases in the second half of this interval, marking the onset of a transgressive trend.

The lower part of Interval B $(45-60 \mathrm{~m})$ consists mainly of "Palorbitolina limestones", with a few levels of requienidgastropod floatstone and of for-algal wackestone-packstone. Lithocodium/Bacinella bindstones occur as dm-thick intercalations from 53.6 to $59.0 \mathrm{~m}$. The upper part $(60-75 \mathrm{~m})$ is mainly made of for-algal wackestones/packstones alternating with a few levels of bio-peloidal packstone-grainstone. Salpingoporella dinarica wackestones-packstone are present at the top. Interval B terminates with a very prominent surface of subaerial exposure, marked by a lens of nodular marly limestones with rounded micritic clasts in a yellowish to greenish marly matrix.

Interval C (75-120 m) starts with the "Orbitolina level", consisting of about $40 \mathrm{~cm}$ of marly limestones crowded with flat low-conical orbitolinids and codiaceans. The "Orbitolina level" is overlain by a few metres of fenestral mudstones and $S$. dinarica wackestones. From 79 to $84 \mathrm{~m}$ the quality of the outcrop is very poor. A few cm-thick beds of green marls are discontinuously exposed under a dense 


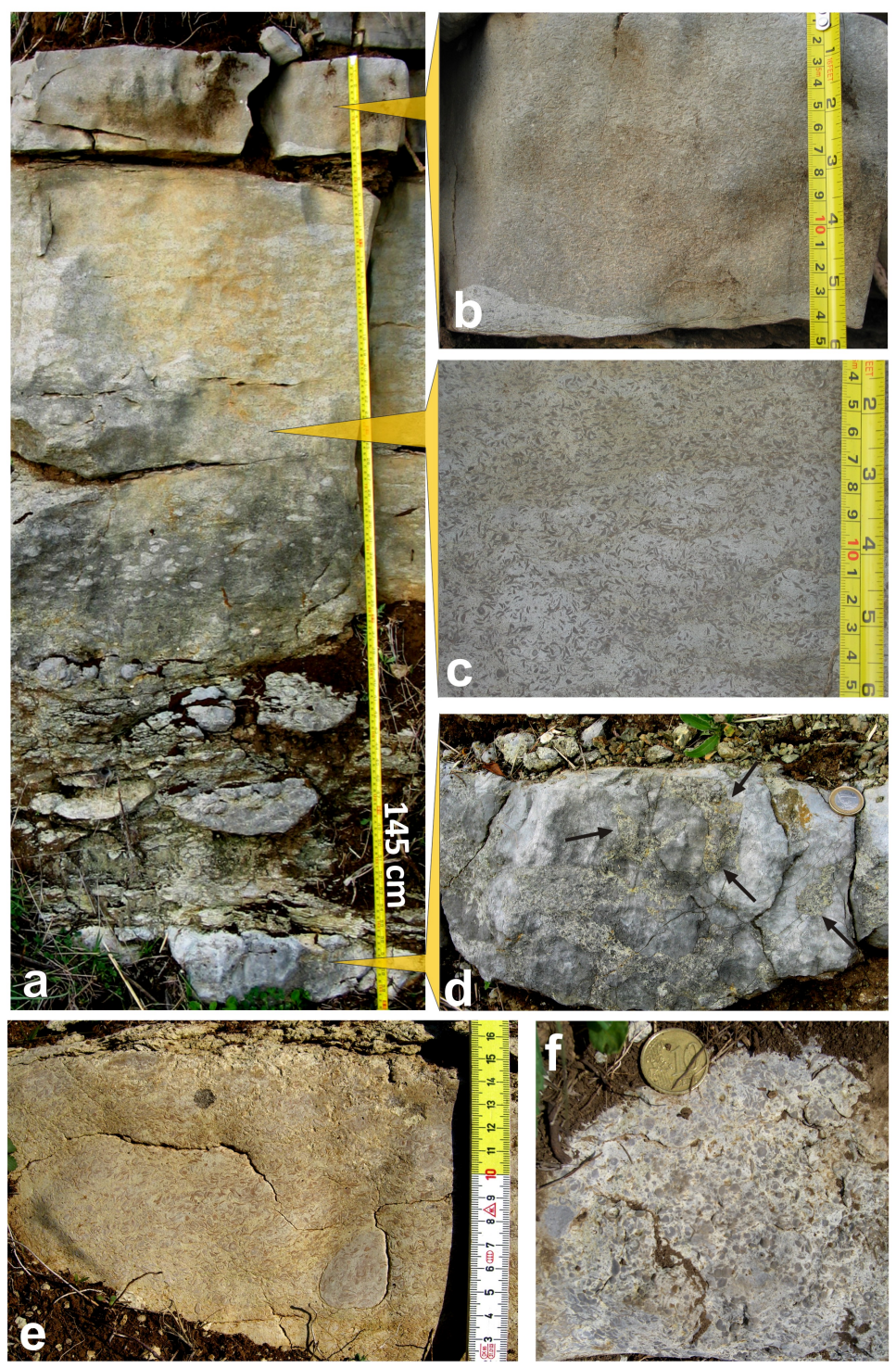

Fig. 6. The "Orbitolina level" at Mt. Tobenna (a) is made by a nodular marly basal interval followed by a marly limestone crowded with flat low-conical orbitolinids (c). At the top there is a bed of orbitolinid-codiacean packstone/grainstone (b). The underlying bed (d) is penetrated by a network of dissolution cavities filled by orbitolinid marly-packstone (see arrows); (e): orbitolinid marly-packstone at Mt. Croce; (f): orbitolinid marly-packstone at Mt. Coccovello.

vegetation cover. The first beds, after this covered interval, consist of dm-thick levels of $S$. dinarica packstones. From about 87 to $112 \mathrm{~m}$ there are m-thick amalgamated beds of bio-peloidal packstone-grainstone, separated by thin levels of mili-ostr-algal mudstone-wackestone and foralgal wackestone. Interval $\mathrm{C}$ ends with $\mathrm{dm}$-thick beds of bio-peloidal packstone-grainstone and for-algal wackestonepackstone, overlain by microbial/fenestral mudstones and chara-ostracodal mudstones-wackestones.

Interval D (120-146.2 m) consists of a regular alternation of dm-thick beds of mili-ostracodal mudstone-wackestone, for-algal wackestone and bio-peloidal packstone-grainstone.
A few beds of partially dolomitized fenestral mudstone occur at the top of the interval.

The following biostratigraphic events have been recognized in the Mt. Croce section (Fig. 8):

- P. infracretacea occurs from the base to the top of the section.

- The FO of $S$. dinarica is at $4.6 \mathrm{~m}$; the first acme is found at $69.8-79.8 \mathrm{~m}$; the second acme is at $86.8-87.8 \mathrm{~m}$; the $\mathrm{LO}$ is at $95.4 \mathrm{~m}$.

- The range of P. lenticularis spans from 45.0 to $60.2 \mathrm{~m}$. 

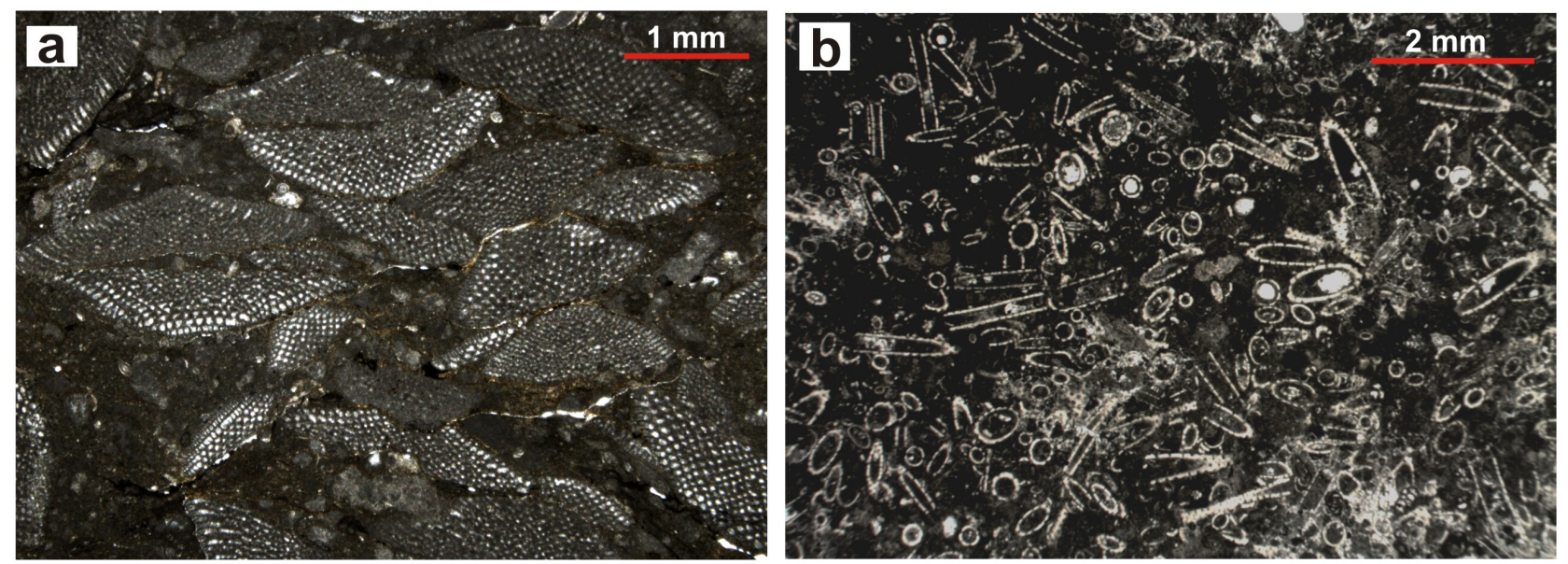

Fig. 7. (a) orbitolinid marly-packstone at Mt. Tobenna, microfacies (sample TB 8.3); (b) Salpingoporella dinarica acme at Mt. Motola, microfacies (sample MO 103.8).

- The FO of V. murgensis is at $52.4 \mathrm{~m}$; the $\mathrm{LO}$ at $65 \mathrm{~m}$.

- D. hahounerensis occurs from 59 to $118 \mathrm{~m}$.

- The "Orbitolina level" is found at $75.9-76.3 \mathrm{~m}$. The first $20 \mathrm{~cm}$ contain exclusively Mesorbitolina parva and M. texana. The upper part contains also B. hochstetteri moncharmontiae.

- The FO of $A$. reicheli is at $112.3 \mathrm{~m}$ but the species becomes abundant from 117.9 to $118.8 \mathrm{~m}$ (A. reicheli level), in concomitance with the FO of C. parva.

\subsubsection{Mt. Raggeto}

The Lower Cretaceous shallow-water carbonates of Mt. Raggeto ( $7 \mathrm{~km}$ northwest of Caserta, $41^{\circ} 09^{\prime} 14^{\prime} \mathrm{N}$, $14^{\circ} 14^{\prime} 51^{\prime}$ E, Fig. 2) have been extensively studied during the last 20 years (D'Argenio et al., 1993, 1999a, 2004; Ferreri et al., 1997; Buonocunto, 1998; Amodio et al., 2003; Wissler et al., 2004). A $97 \mathrm{~m}$-thick section was logged, starting about $30 \mathrm{~m}$ below the thin bedded limestones identified by Wissler et al. (2004) as the equivalent of the Selli level. Based on lithofacies associations, this section has been subdivided into three intervals (A-C) (Fig. 9).

Interval A (0-39.3 m) starts with a few metres of biopeloidal packstones with nubecularids, followed by for-algal wackestones with Lithocodium/Bacinella nodules and bioturbated wackestones with Palorbitolina. Dolomite-filled Thalassinoides burrows make a tridimensional network that is well visible on weathered surfaces. After a $9 \mathrm{~m}$ thick interval of no exposure, the log continues in an abandoned quarry. At the base of the quarry wall there is a $7.5 \mathrm{~m}$-thick dolomitized interval, made of massive dolomites and thinly bedded dolomitized mudstones-wackestones. It corresponds roughly to the superbundle "14" of Wissler et al. (2004) that, according to Amodio et al. (2003), consists mainly of Palorbitolina wackestone-packstones. Even if dolomitized limestones are not reported in the Wissler et al. (2004) log, their presence is confirmed by the abrupt shift of about $2 \%$ in the $\delta^{18} \mathrm{O}$ at this level (see Fig. 3 of Wissler et al., 2004). This dolomitized interval is followed by about $6 \mathrm{~m}$ of well bedded bio-peloidal packstones with nubecularids and foralgal wackestones-packstones with Lithocodium/Bacinella nodules, alternating with floatstones with requienids and ostreids.

The last part of the interval A is characterized by poorly exposed thin beds of bio-peloidal packstone with nubecularids, alternating with ostracodal mudstones-wackestones.

Interval B $(39.3-75 \mathrm{~m})$ is mainly made of algal wackestones-packstones rich of $S$. dinarica, with a few beds of requienid floatstones and of bio-peloidal packstones. Lithocodium/Bacinella nodules are particularly abundant between 45.5 and $53 \mathrm{~m}$ from the base of the section, associated with requienid floatstones. In the upper part of this interval, between 62 and $69 \mathrm{~m}$ from the base of the section, some beds of chara-ostracodal mudstones mark a regressive trend culminating with a cluster of nodular marly levels.

Interval C (75-97.3 m) is mainly made of bio-peloidal packstones-grainstones. At the base they alternate with some beds of ostreid-requienid floatstones, while in the uppermost part (from 87 to $97.3 \mathrm{~m}$ from the base of the section) there are some intercalations of mili-ostracodal mudstone-wackestones. The section ends with a few beds of foraminiferal wackestones with primitive forms of $A$. reicheli and nodules of Lithocodium/Bacinella.

The following biostratigraphic events were recognized in the Mt. Raggeto section (Fig. 9):

- P. infracretacea is present from the base to the top of the section. 


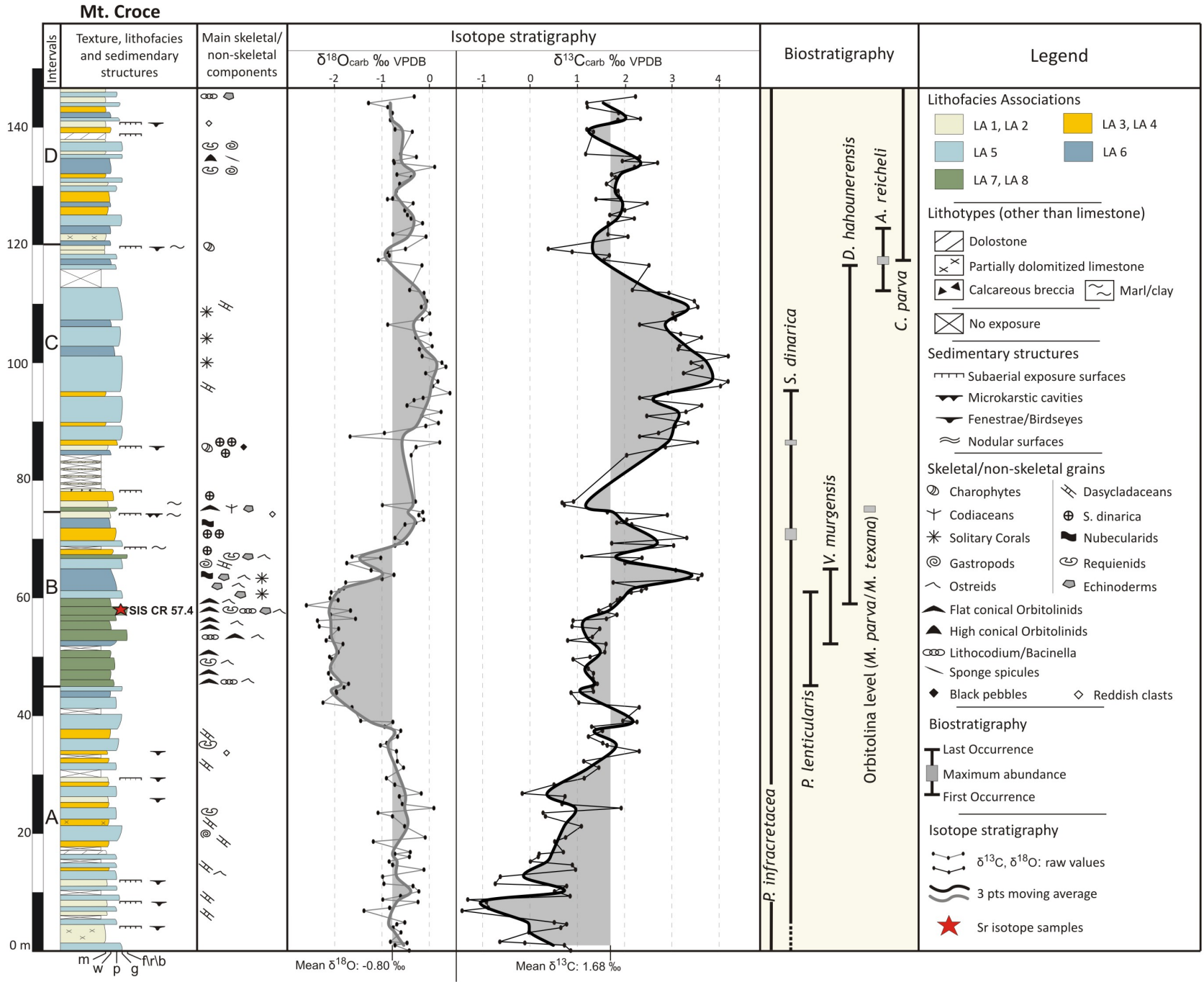

Fig. 8. Mt. Croce section: lithological-sedimentological log, isotope stratigraphy and biostratigraphy. The thick curves represent the 3-point moving averages of $\mathrm{O}-$ (grey) and $\mathrm{C}$-isotope ratios (black).

- S. dinarica occurs from the base of the section to $82.5 \mathrm{~m}$; a first interval of maximum abundance occurs between 43 to $53 \mathrm{~m}$ from the base of the section; the second acme is between 70 and $73 \mathrm{~m}$.

- P. lenticularis has been found from 6 to $24 \mathrm{~m}$ from the base of the section.

- D. hahounerensis occurs from $39.8 \mathrm{~m}$ to the top of the section.

- The FO of A. reicheli and C. parva is at $76.3 \mathrm{~m}$.

\subsubsection{Mt. Tobenna}

This section is $48.5 \mathrm{~m}$ thick (Fig. 10) and was logged on the southern slope of Monte Tobenna in the Picentini Mountains, about $8 \mathrm{~km}$ northeast of Salerno (Fig. 2). This is a classical locality for the "Orbitolina level" of southern Apennines (De Castro, 1963; Cherchi et al., 1978). The lower half of the section (from 0 to $24 \mathrm{~m}$ ) is exposed in an abandoned quarry $\left(40^{\circ} 42.01^{\prime \prime} \mathrm{N}, 14^{\circ} 51^{\prime} 43^{\prime \prime} \mathrm{E}\right)$ and has been the object of many papers dealing mainly with cyclostratigraphy (Raspini, 1998, 2011; D’Argenio et al., 1999b, 2004). The section continues on the mountain slope above the edge of the quarry.

On the basis of the LA trends, the section can be clearly divided into two intervals (A and $\mathrm{B})$. In interval $\mathrm{A}(0$ $24 \mathrm{~m}$ ), which has been logged in the quarry wall, the exceptional quality of the exposure permitted unusual highresolution observation of the $\mathrm{mm}$ - to dm-thick marly layers that are found at the top of many limestone beds. In the upper part of the section, the thinnest marly levels are observed as mm-thick recessive partings between 


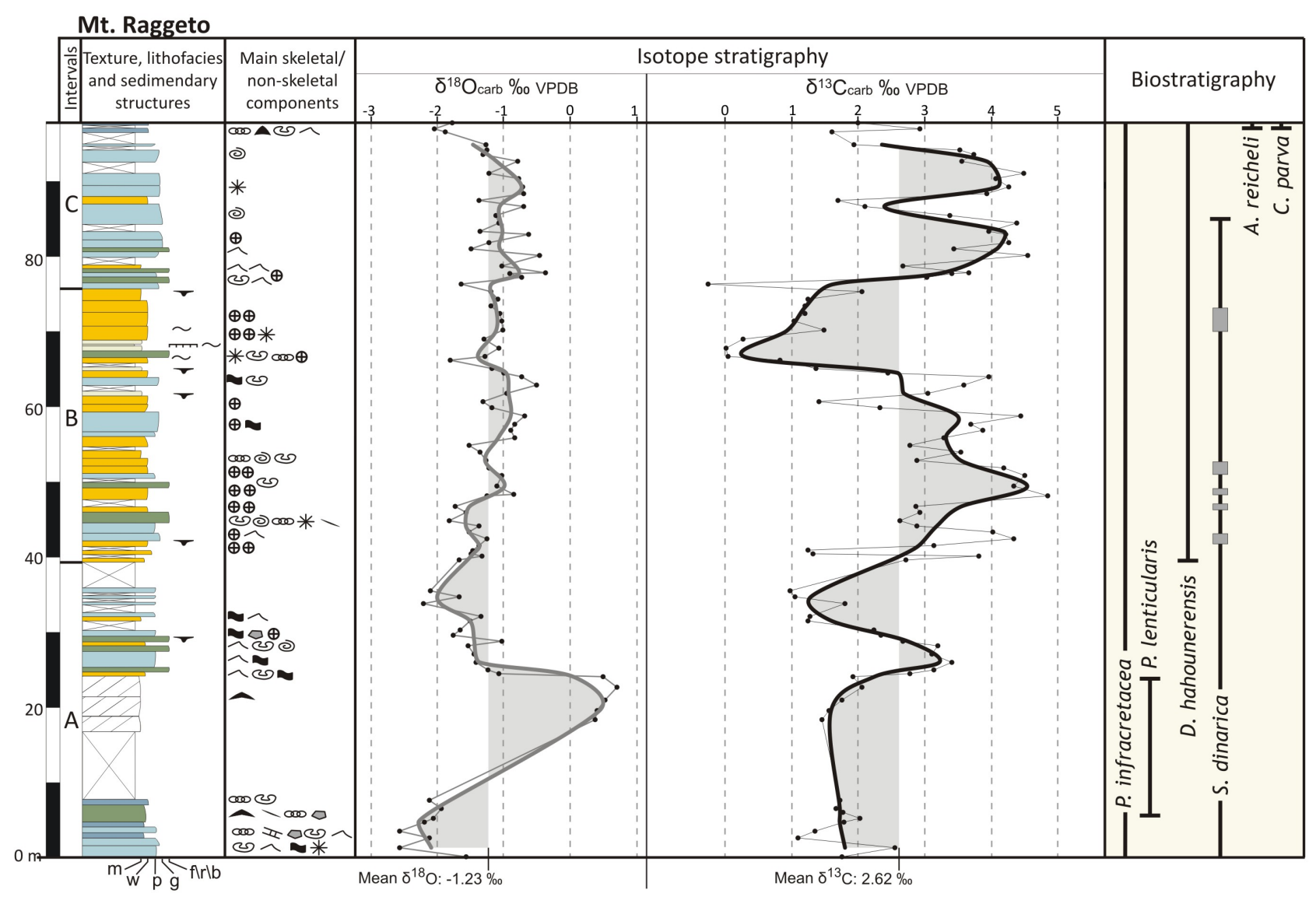

Fig. 9. Mt. Raggeto section: lithological-sedimentological log, isotope stratigraphy and biostratigraphy. The thick curves represent the 3-point moving averages of O- (grey) and C-isotope ratios (black). See Fig. 8 for a key to colours, patterns and symbols.

limestone beds, while the thickest levels probably corresponds to poorly exposed and densely vegetated parts of the slope. The first part of interval A $(0-7 \mathrm{~m})$ consists mainly of an alternation of chara-ostracodal mudstones-wackestones, bio-peloidal packstones-grainstones with nubecularids, and mili-ostracodal wackestones. Between 7 and $15 \mathrm{~m}$ from the base of the section, the most frequent lithofacies consists of algal wackestones-packstones with $S$. dinarica, alternating with bio-peloidal packstone-grainstones. A prominent bed of requienid floatstone is present at $11 \mathrm{~m}$ from the base of the section. The "Orbitolina level" occurs at $15 \mathrm{~m}$ from the base of the section. It is composed by two beds. The lower bed is a $120 \mathrm{~cm}$ thick bioturbated marly limestone crowded with flat low-conical orbitolinids; the argillaceous component decreases upward. The upper bed, which is just $15 \mathrm{~cm}$ thick, is separated by the lower bed by a wavy erosional surface and consists of a packstone/grainstone crowded with flat low-conical orbitolinids and codiacean algae (Boueina hochstetteri moncharmontiae). Below the wavy base of the "Orbitolina level", the underlying bed is penetrated down to about $1 \mathrm{~m}$ by a dense network of dissolution cavities filled by orbitolinid packstone (Fig. 6).
The "Orbitolina level" is overlain by $70 \mathrm{~cm}$ of bio-peloidal packstones-grainstones. The remaining part of interval A is dominated by chara-ostracodal mudstones-wackestones alternating with $\mathrm{cm}$ - to $\mathrm{dm}$ - thick levels of greenish marls. The thickest marly levels contain nodules of chara-ostracodal mudstones. Interval B (24-48.5 m) was logged on the mountain slope immediately west of quarry edge. It is dominated by bio-peloidal packstones-grainstones with abundant benthic foraminifers, with a few beds of mili-ostracodal mudstones-wackestones. Lithocodium/Bacinella nodules are a frequent component between 26 and $36 \mathrm{~m}$ from the base of the section. The section ends with a bed of foraminiferal packstone crowded with $A$. reicheli.

The following biostratigraphic events have been recognized in the Mt. Tobenna section (Fig. 10):

- P. infracretacea occurs from the base to the top of the section.

- S. dinarica is found from the base of the section to $24 \mathrm{~m}$; an interval of maximum abundance is observed between 9 and $14.6 \mathrm{~m}$ from the base of the section. 


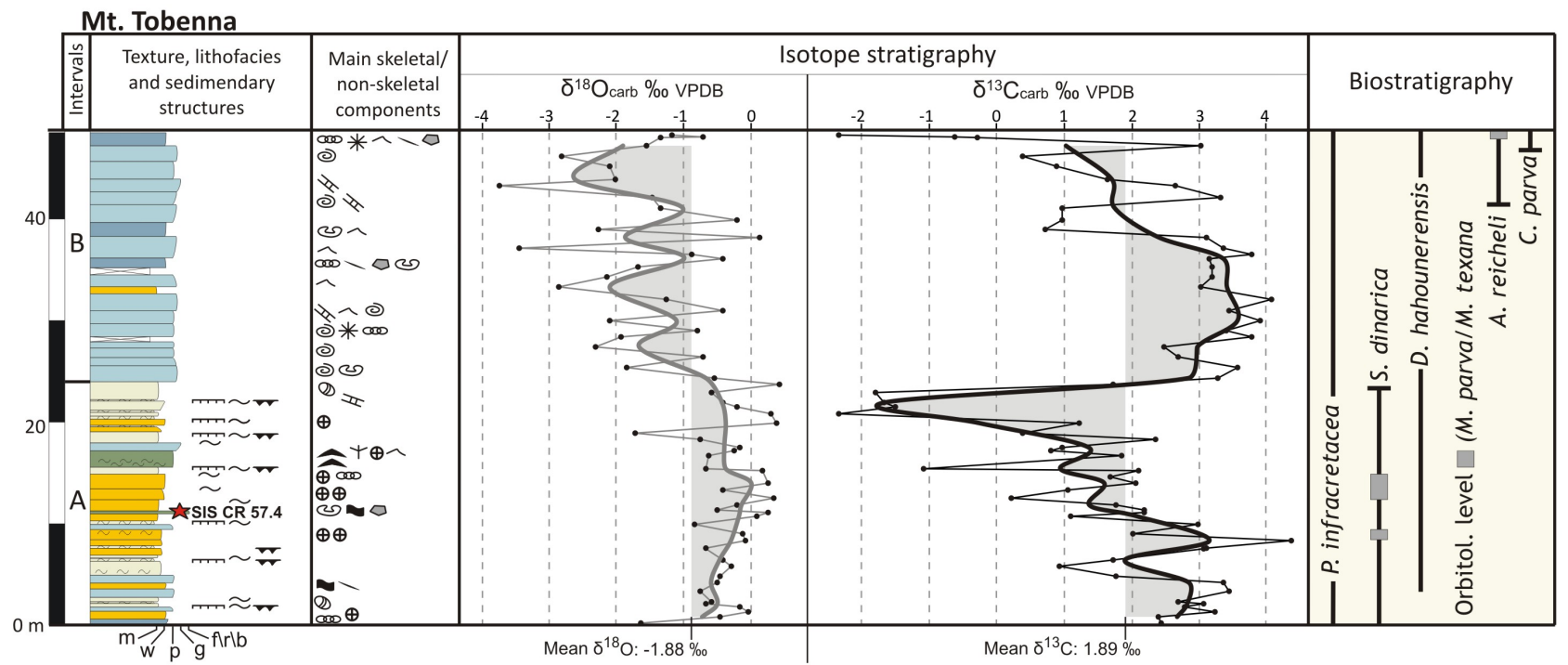

Fig. 10. Mt. Tobenna section: lithological-sedimentological log, isotope stratigraphy and biostratigraphy. The thick curves represent the 3-point moving averages of O- (grey) and C-isotope ratios (black). See Fig. 8 for a key to colours, patterns and symbols.

- D. hahounerensis occurs from $3.3 \mathrm{~m}$ to the top of the section.

- The "Orbitolina level" is at 15.5-17.2 from the base of the section. It is crowded with the flat low-conical shells of M. parva and M. texana. The codiacean alga $B$. hochstetteri moncharmontiae is particularly abundant in the packstone/grainstone at the top of the level.

- The FO of A. reicheli is at $41.1 \mathrm{~m}$ where primitive specimens are first observed. The $A$. reicheli level, containing a rich association of typical specimens of this species, is found at $48.1 \mathrm{~m}$ from the base of the section

- The FO of C. parva is at $46.2 \mathrm{~m}$.

\subsubsection{Mt. Motola}

This section was logged on the southern slope of Mt. Motola $\left(40^{\circ} 21^{\prime} 53^{\prime \prime} \mathrm{N}, 15^{\circ} 25^{\prime} 42^{\prime \prime} \mathrm{E}\right)$, about $65 \mathrm{~km}$ southeast of Salerno (Fig. 2). It is $150.3 \mathrm{~m}$ thick and has been subdivided into four intervals (Fig. 11). Interval A $(0-75 \mathrm{~m})$ consists mainly of bio-peloidal packstones-grainstones, mili-ostralgal mudstones-wackestones and microbial/fenestral mudstones. Two levels of for-algal packstone and requienidgastropod floatstone occur in the uppermost part. The first $20 \mathrm{~m}$ are dominated by peritidal $\mathrm{m}$-thick SU cycles. Subaerial exposure surfaces at the top of the cycles are marked by discontinuous levels of greenish/yellowish marls, infiltrating downwards into microkarstic cavities. Subtidal facies become predominant upwards, marking the onset of a deepening trend, but subaerial exposure surfaces are still present at the top of some cycles. Interval B $(75-98 \mathrm{~m})$ is dominated by subtidal facies. It consists mainly of Palorbitolina wackestones with sponge spicules and echinoderm fragments, alternating with requienid-gastropod floatstones. $\mathrm{Cm}$ - to $\mathrm{dm}$ thick beds of Lithocodium/Bacinella bindstone are present at the base of this interval. A m-thick bed of packstone crowded with nubecularid foraminifers occurs at the top. This interval terminates with a prominent subaerial exposure surface, marked by microkarstic cavities with greenish marly infilling.

At the base of interval C (98-126 m), there are about three metres of very poorly exposed section. Centimetric discontinuous marly levels are hardly visible under a thick vegetation and soil cover. The following beds are made of $S$. dinarica packstones alternating with 10 to $50 \mathrm{~cm}$-thick levels of chara-ostracod and mili-ostr-algal mudstone-wackestone, capped by subaerial exposure surfaces. From 107 to $122 \mathrm{~m}$, interval $\mathrm{C}$ consists mainly of very thick amalgamated beds (up to $6 \mathrm{~m}$-thick) of bio-peloidal packstone-grainstone, with a few decimetric intercalations of gastropod-requienid floatstone. The uppermost part of the interval $(122-126 \mathrm{~m})$ is made of $\mathrm{dm}$ to $\mathrm{m}$-thick beds of bio-peloidal packstonegrainstone alternating with microbial/fenestral mudstones capped by thin seams of marls, which infiltrates downward into microkarstic cavities. Interval D (126-150.3 m) is mainly made of bio-peloidal packstones-grainstones and mili-ostracodal mudstones-wackestones. Microbial/fenestral mudstones, capped by subaerial exposure surfaces, are present in the uppermost part of the section.

The following biostratigraphic events have been documented in the Mt. Motola section (Fig. 11):

- The FO of $P$. infracretacea is at $23 \mathrm{~m}$; the range of this species extends beyond the top of this section. 


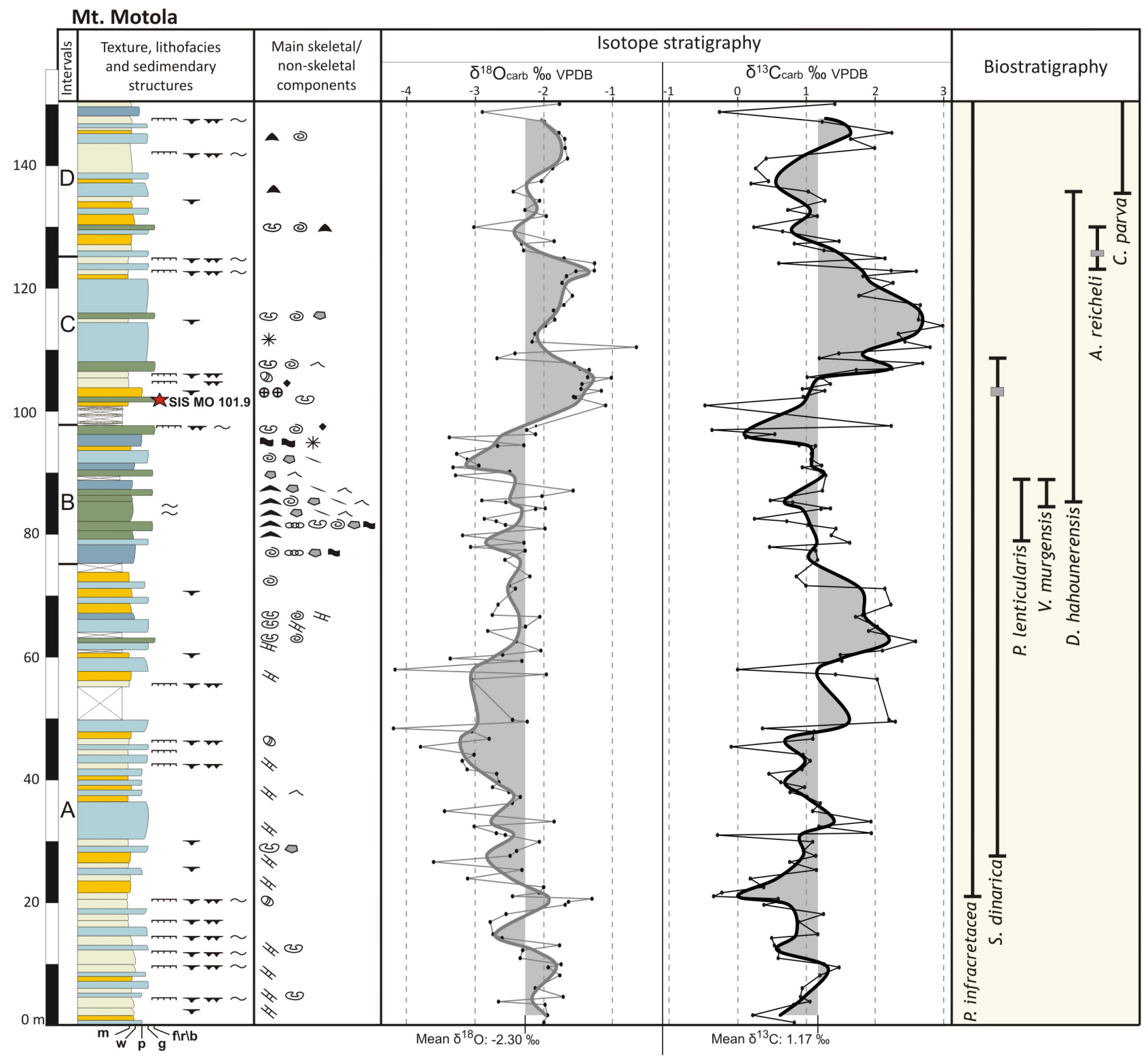

Fig. 11. Mt. Motola section: lithological-sedimentological log, isotope stratigraphy and biostratigraphy. The thick curves represent the 3-point moving averages of O- (grey) and C-isotope ratios (black). See Fig. 8 for a key to colours, patterns and symbols.

- The FO of $S$. dinarica is at $27.6 \mathrm{~m}$; the acme is at $103.5-$ $104 \mathrm{~m}$, the $\mathrm{LO}$ is at $109.6 \mathrm{~m}$.

- The range of P. lenticularis spans from 79.2 to $89.7 \mathrm{~m}$.

- The FO and LO of V. murgensis are placed at 84 and $89.7 \mathrm{~m}$ respectively.

- D. hahounerensis occurs from 85.4 to $137.3 \mathrm{~m}$.

- The range of A. reicheli spans from 123 to $126.4 \mathrm{~m}$; the maximum abundance ("A. reicheli level") is observed at 125.1 to $126.4 \mathrm{~m}$.
- The FO of C. parva is at $137.3 \mathrm{~m}$.

The "Orbitolina level" is missing in this section. Biolithostratigraphic correlation suggests that it is lost in the gap associated with the prominent subaerial exposure surface at the boundary between intervals B and C.

\subsubsection{Mt. Coccovello}

This $135.2 \mathrm{~m}$-thick composite section was logged on the southern slope of Mt. Coccovello $\left(40^{\circ} 02^{\prime} 38^{\prime \prime} \mathrm{N}\right.$, $15^{\circ} 42^{\prime} 32^{\prime \prime} \mathrm{E}$ ), about $3 \mathrm{~km}$ north of Maratea (Fig. 2). It has been subdivided into four intervals (A-D) based on 


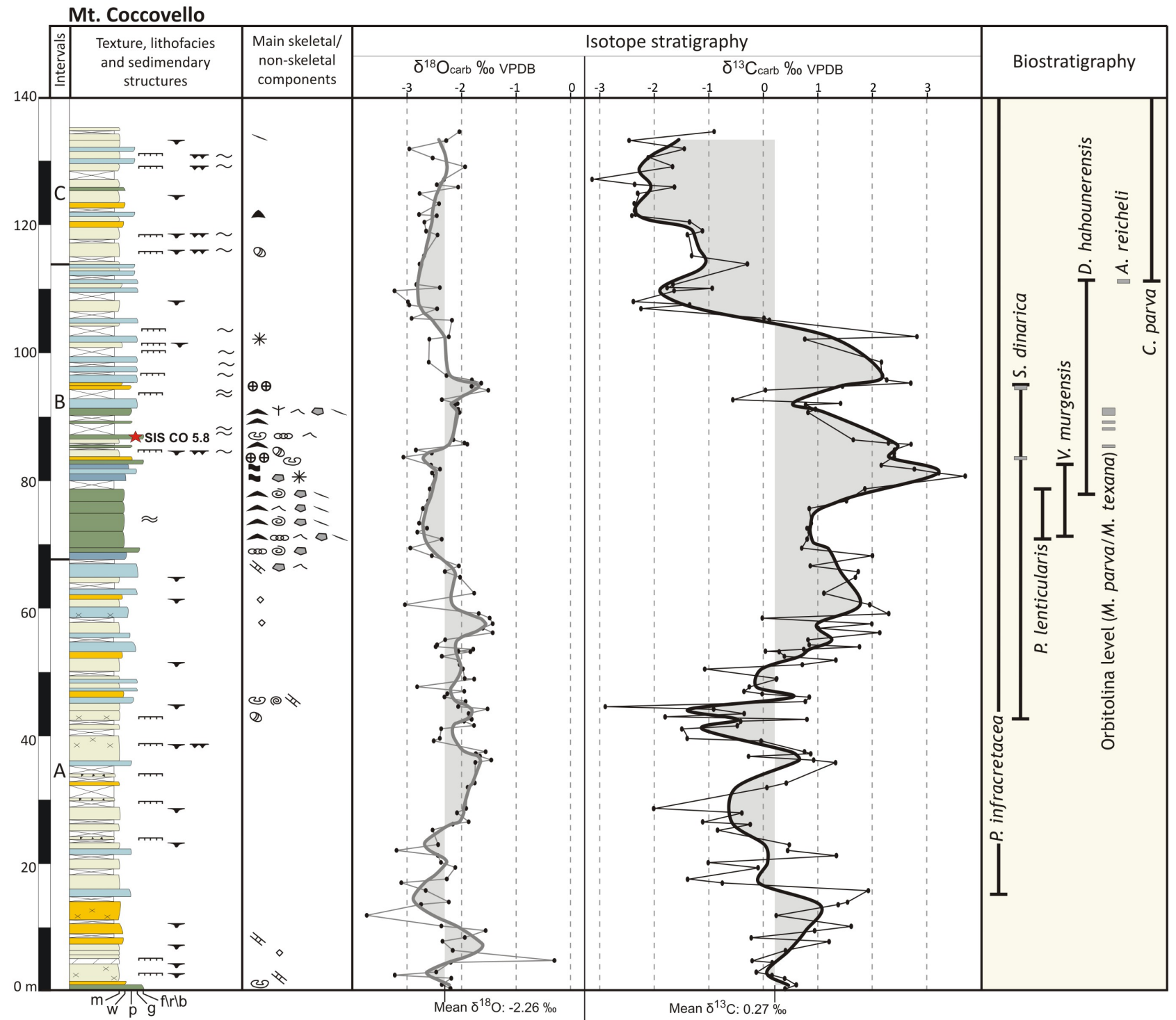

Fig. 12. Mt. Coccovello section: lithological-sedimentological log, isotope stratigraphy and biostratigraphy. The thick curves represent the 3-point moving averages of O- (grey) and C-isotope ratios (black). See Fig. 8 for a key to colours, patterns and symbols.

the major changes of lithofacies associations and on the occurrence of some prominent subaerial exposure surfaces (Fig. 12). Interval A (0-67.2 m) is dominated by intertidal microbial/fenestral mudstones alternating with mili-ostralgal mudstones-wackestones and bio-peloidal packstonesgrainstones. The latter become more frequent in the upper part of the interval, highlighting the onset of a deepening trend. Subaerial exposure surfaces are frequent at the base and from 22 to $42 \mathrm{~m}$.

The lower part of interval B, from 67.2 to $79.1 \mathrm{~m}$, consists mainly of Palorbitolina wackestones. About $2 \mathrm{~m}$ of Lithocodium/Bacinella bindstone occur in the lowermost part of the interval (from 69 to $71 \mathrm{~m}$ ). The upper part (from 80 to $85 \mathrm{~m}$ ) is made of dm-thick beds of for-algal wackestone-packstone, crowded with nubecularid foraminifers, overlain by a bed of S. dinarica packstone. The interval terminates with a bed of microbial/fenestral mudstone, capped by a subaerial exposure surface. Interval $\mathrm{C}$ $(85-120 \mathrm{~m})$ starts with a thin marly level crowded with flat low-conical orbitolinids, followed by a distinctive requienid floatstone. The orbitolinid marls penetrate downwards into a network of microkarstic cavities. From 87 to $91 \mathrm{~m}$ the section is characterized by very poor exposure, with discontinuous $\mathrm{cm}$-thick orbitolinid marls cropping out from a dense vegetation and soil cover. A bed of orbitolinid-codiacean packstone terminates this poorly exposed portion. The next segment (from 92 to $119 \mathrm{~m}$ ) consists mainly of bio-peloidal packstones-grainstones alternating with microbial/fenestral 
mudstones. The uppermost five metres of interval $\mathrm{C}$ are almost entirely made of chara-ostracod mudstones and fenestral mudstones, capped by subaerial exposure surfaces. Interval D (119-135.2 m) is mainly made of an alternation of bio-peloidal packstones-grainstones and microbial/fenestral mudstones, with a few beds of mili-ostracodal mudstonewackestone. A couple of prominent subaerial exposure surfaces occur in the upper part of this interval.

The following biostratigraphic events were recognized in the Mt. Coccovello section (Fig. 10):

- P. infracretacea first occurs at $15.6 \mathrm{~m}$ and is present up to the top of the section.

- The FO of $S$. dinarica is at $42.3 \mathrm{~m}$; its first acme is at $84.3 \mathrm{~m}$, the second acme is at $94.5 \mathrm{~m}$.

- P. lenticularis is present from 70.8 to $79.1 \mathrm{~m}$.

- The FO and LO of V. murgensis are placed at 70.8 and $82.4 \mathrm{~m}$ respectively.

- D. hahounerensis occurs from 78.7 to $87 \mathrm{~m}$.

- The base of the "Orbitolina level" is a 5 to $10 \mathrm{~cm}$-thick discontinuous marly layer which occurs at $85.0 \mathrm{~m}$ above a prominent subaerial exposure surface and infiltrates downward into microkarstic cavities. This level contains M. parva and M. texana. Other cm-thick discontinuous marly levels with the same microfauna occur across a $5 \mathrm{~m}$ thick interval of poor exposure. The typical packstone with Mesorbitolina and the codiacean alga $B$. hochstetteri moncharmontiae, which elsewhere represents the top of the "Orbitolina level", occurs at $91.2 \mathrm{~m}$.

- The A. reicheli level corresponds to a $20 \mathrm{~cm}$-thick layer at $110.8 \mathrm{~m}$.

\subsection{Carbon and strontium isotope stratigraphy}

\subsubsection{Mt. Croce}

One hundred and fifty samples were analyzed for the Mt. Croce section (Fig. 8). The $\delta^{13} \mathrm{C}$ values range between $-1.4 \%$ and $+4.2 \%$, with an average value of $+1.7 \%$. The lower part of the $\delta^{13} \mathrm{C}$ curve shows a rising trend with superimposed higher frequency fluctuations. Carbon isotope ratios increase from slightly negative values at the base of the section to a maximum of $+2.1 \%$ at $39.1 \mathrm{~m}$, about $6 \mathrm{~m}$ below the base of the "Palorbitolina limestones". After a $1 \%$ o decrease, the $\delta^{13} \mathrm{C}$ curve makes a plateau at about $+1 \%$, which corresponds almost entirely to the "Palorbitolina limestones". This plateau is followed by a marked positive excursion which starts $4 \mathrm{~m}$ below the top of the "Palorbitolina limestones", peaks at about $+3 \%$ and then decreases to pre-excursion values of $+1 \%$ at $76.5 \mathrm{~m}$, just above the "Orbitolina level". From there it starts a new very broad positive excursion that peaks at about $+4 \%$ o $10 \mathrm{~m}$ above the second acme of $S$. dinarica, and returns at pre-excursion values $1 \mathrm{~m}$ above the $A$. reicheli level. The last part of the $\delta^{13} \mathrm{C}$ curve is characterized by values fluctuating between +1 and $+2 \%$.

Three fragments of requienid shells from a floatstone at $57.4 \mathrm{~m}$ from the base of the section, $3 \mathrm{~m}$ below the top of the "Palorbitolina limestones", have been analysed for SIS. Their ${ }^{87} \mathrm{Sr} /{ }^{86} \mathrm{Sr}$ mean value gives a numerical age of $124.1 \mathrm{Ma}$ (Table 2).

\subsubsection{Mt. Raggeto}

Ninety-two samples, among which five dolomites, were analyzed for the Mt. Raggeto section. The $\delta^{13} \mathrm{C}$ values range between $-0.2 \%$ and $+4.8 \%$, with an average value of $+2.6 \%$ o (Fig. 9). In the first part of the curve (0-22 m), corresponding to the "Palorbitolina limestones" and to the thick dolomitic interval, there is a plateau at about $+1.6 \%$, with superimposed high- frequency fluctuations between +1 and $+2 \%$. Then, there is a sharp positive excursion of about $1.5-2 \%$, which peaks at $+3.4 \%$ at $25.9 \mathrm{~m}$ from the base of the section. This is followed by a very broad positive excursion, which occupies all the central part of the logged section, reaching peak values of nearly $+5 \%$ at about $50 \mathrm{~m}$ from the base of the section, at a level corresponding to the first interval of maximum abundance of $S$. dinarica. A stepped decline, with superimposed high-frequency fluctuations, leads to a minimum value of about $0 \%$ at $67 \mathrm{~m}$ from the base of the section, just below the second interval of maximum abundance of $S$. dinarica. The $\delta^{13} \mathrm{C}$ curve ends with another positive excursion showing two positive peaks at about $+4 \%$, separated by a relative minimum of about $+2 \%$ at $87 \mathrm{~m}$ from the base of the section. The last few metres of the sections are marked by a steep decrease to values of about $+1.6 \%$.

\subsubsection{Mt. Tobenna}

Sixty-five samples were analyzed for the Mt. Tobenna section. The $\delta^{13} \mathrm{C}$ values range between $-2.4 \%$ and $+4.4 \%$, with an average of $+1.9 \%$ (Fig. 10). The first $10 \mathrm{~m}$ of the curve are characterized by wildly fluctuating values with two closely spaced positive excursions peaking at $+3.5 \%$ and at $+4.4 \%$. Then there is a prolonged decreasing trend, with superimposed high-frequency fluctuations, reaching a minimum value of $-2.3 \%$ a few metres above the "Orbitolina level", in correspondence of a cluster of dm-thick greenish marly levels indicating prolonged subaerial exposure. From this minimum there is a very sharp rise to a value of $+3.5 \%$ o at $25.4 \mathrm{~m}$ from the base of the section, just above the last occurrence of $S$. dinarica. After a positive plateau, defined by $\delta^{13} \mathrm{C}$ values oscillating mainly between +3 and $+4 \%$, there is a decreasing trend with superimposed high-frequency fluctuations. Very depleted values of $-2.4 \%$ are reached at the end of the section, in correspondence of the A. reicheli level. 
Three fragments of requienid shells from a floatstone occurring $5.8 \mathrm{~m}$ below the base of the "Orbitolina level" have been analysed for SIS. After discarding as altered one shell, because of its low Sr concentration $(<550 \mathrm{ppm})$, the ${ }^{87} \mathrm{Sr} /{ }^{86} \mathrm{Sr}$ mean value of the two well preserved shells gives a numerical age of $119.9 \mathrm{Ma}$ (Table 2).

\subsubsection{Mt. Motola}

One hundred and thirty-seven samples were analyzed for the Mt. Motola section (Fig. 11). The $\delta^{13} \mathrm{C}$ values range between $-0.5 \%$ and $+3 \%$, with an average value of $+1.2 \%$. The first part of the smoothed $\delta^{13} \mathrm{C}$ curve shows an overall rising trend, reaching a peak of about $+2.2 \%$ at $62.6 \mathrm{~m}$, about $16.6 \mathrm{~m}$ below the base of the "Palorbitolina limestones". From this peak, $\delta^{13} \mathrm{C}$ values decrease and then make a plateau, roughly corresponding to the "Palorbitolina limestones", defined by values fluctuating around $+1 \%$. After a very sharp decrease to $0 \%$, there is a broad positive excursion, peaking at about $+2.8 \%$ o some $11 \mathrm{~m}$ above the acme of S. dinarica and returning at values of about $+1 \%$ o $4 \mathrm{~m}$ above the $A$. reicheli level. The $\delta^{13} \mathrm{C}$ curve terminates with a rising trend to a peak of about $+1.6 \%$.

Four fragments of requienid shells, contained in a floatstone occurring immediately below the acme of $S$. dinarica (at $101.9 \mathrm{~m}$ from the base of the section), have been analysed for SIS. Their ${ }^{87} \mathrm{Sr} /{ }^{86} \mathrm{Sr}$ mean value gives a numerical age of 119.1 Ma (Table 2).

\subsubsection{Mt. Coccovello}

One hundred and twenty-nine samples were analyzed for the Mt. Coccovello section (Fig. 12). The $\delta^{13} \mathrm{C}$ values range between $-3.1 \%$ and $+3.7 \%$ o, with an average value of $+0.3 \%$ o. The first part of the $\delta^{13} \mathrm{C}$ smoothed curve shows an overall decreasing trend, from $+0.3 \%$ at the base to $-1.3 \%$ at $44 \mathrm{~m}$, with superimposed higher frequency fluctuations. Then there is a rising trend, peaking at about $+1.8 \%$ o $8 \mathrm{~m}$ below the base of the "Palorbitolina limestones". From this peak, $\delta^{13} \mathrm{C}$ values decrease to about $+1 \%$ and stay around this value for most of the interval corresponding to the "Palorbitolina limestones". Then there is a prominent positive excursion, peaking at $+3.2 \%$ some $2 \mathrm{~m}$ above the top of the "Palorbitolina limestones" and declining to a minimum of $+0.6 \% 00.5 \mathrm{~m}$ above the top of the "Orbitolina level".

After a sharp positive shift to about $+2.1 \%$, there is a very marked decrease to a minimum of $-1.9 \%$, roughly corresponding to the $A$. reicheli level. The $\delta^{13} \mathrm{C}$ curve terminates with a rebound to $-1 \%$, followed by a new decrease to $-2.2 \%$.

Three fragments of requienid shells from a floatstone at $86.4 \mathrm{~m}$ from the base of the section, $1 \mathrm{~m}$ above the first level of marls with Mesorbitolina, have been analysed for SIS. Their ${ }^{87} \mathrm{Sr} /{ }^{86} \mathrm{Sr}$ mean value gives a numerical age of 122.9 Ma (Table 2).

\section{Interpretation and discussion}

\subsection{Reliability of the $\delta^{13} \mathrm{C}$ record}

During the last two decades C-isotope stratigraphy has been successfully applied to high resolution dating and correlation of Cretaceous carbonate platforms (Wagner, 1990; Jenkyns, 1995; Ferreri et al., 1997; Masse et al., 1999; D’Argenio et al., 2004; Wissler et al., 2004; Parente et al. 2007; Burla et al., 2008; Vahrenkamp, 2010; Huck et al., 2011; Millán et al., 2011). On the other hand, it is well known that, besides post-depositional diagenetic alteration (Dickson and Coleman, 1980; Allan and Matthews, 1982; Lohmann, 1988; Marshall, 1992), biological fractionation and local palaeoceanographic conditions may cause the carbon isotope signal of platform carbonates to deviate from the open ocean global signal (Weber and Woodhead, 1969; Patterson and Walter, 1994; see Immenhauser et al., 2008, for a recent review). A recent study concluded that, in Kimmeridgian shallow-water carbonates of the Jura Mountains, the general trend of $\delta^{13} \mathrm{C}$ values faithfully records the long-term global variations of the open ocean while higher order fluctuations "might result from variations in local environmental conditions on the shallow platform" (Colombié et al., 2011).

Therefore, before attempting a correlation with the reference curves of pelagic and hemipelagic successions, the stable isotope record of the studied successions was carefully scrutinized in order to assess if it is significantly biased by diagenesis and/or by local environmental conditions.

Below subaerial exposure surfaces $\delta^{13} \mathrm{C}$ values are commonly depleted, implying the influence of soil-derived $\mathrm{CO}_{2}$, while $\delta^{18} \mathrm{O}$ values may be enriched because of the preferential removal of ${ }^{16} \mathrm{O}$ in the pore waters through evaporation (Allan and Matthews, 1982; Joachimski, 1994).

Diagenesis in the vadose zone is generally characterized by depleted $\delta^{18} \mathrm{O}$ values and highly variable $\delta^{13} \mathrm{C}$. Strong covariation between $\delta^{13} \mathrm{C}$ and $\delta^{18} \mathrm{O}$ is taken as proof of diagenetic alteration of the stable isotope signal under the influx of meteoric water in the mixing zone (Allan and Matthews, 1982), or as a trend of progressively decreasing alteration within the freshwater phreatic zone (Swart, 2011).

The scatter plots of carbon and oxygen isotope ratios (Fig. 13) show that the covariance between $\delta^{13} \mathrm{C}$ and $\delta^{18} \mathrm{O}$ values is very low to moderate for the five studied sections $(r=0.01-0.46)$. However, some lithofacies associations show higher correlation coefficients (Table 3 ) that could be partly the result of mixing-zone diagenesis or of alteration within the freshwater phreatic zone. Some very negative $\delta^{13} \mathrm{C}$ values $(<2 \%$ ), especially at Mt. Coccovello and Mt. Tobenna, are associated with subaerial exposure surfaces. Evaporation during exposure is probably also responsible for $\delta^{18} \mathrm{O}$ values $>0 \%$ in the first part of the Mt. Tobenna section. Conversely, some very depleted $\delta^{18} \mathrm{O}$ values $(<-3 \%$ ) , especially at Mt. Motola and in the upper part of 
Table 2. Elemental concentration, Sr-isotope ratio and SIS age

\begin{tabular}{|c|c|c|c|c|c|c|c|c|c|c|c|}
\hline \multirow[t]{2}{*}{ Section } & \multirow[t]{2}{*}{ Sample no. } & \multirow[t]{2}{*}{ Component } & \multirow[t]{2}{*}{$\mathrm{Sr}$} & \multirow[t]{2}{*}{$\mathrm{Mg}$} & \multirow{2}{*}{$\begin{array}{c}\mathrm{Fe} \\
\mathrm{ppm}]\end{array}$} & \multirow[t]{2}{*}{ Mn } & \multirow[t]{2}{*}{${ }^{87} \mathrm{Sr} /{ }^{86} \mathrm{Sr}$} & \multirow{2}{*}{$\begin{array}{l} \pm 2 \text { s.e. } \\
\left(* 10^{-6}\right)\end{array}$} & \multicolumn{3}{|c|}{ Age $[\mathrm{Ma}]$} \\
\hline & & & & & & & & & Min & Mean & Max \\
\hline \multirow[t]{5}{*}{ Motola } & MO 101.9A & requienid & 1232 & 2351 & 19.1 & 6.3 & 0.707313 & & & & \\
\hline & MO 101.9B & requienid & 899 & 1053 & 26.6 & 1.4 & 0.707323 & & & & \\
\hline & MO 101.9D & requienid & 949 & 1007 & 28.9 & 1.6 & 0.707309 & & & & \\
\hline & MO 101.9E & requienid & 933 & 987 & 23.4 & 0.5 & 0.707308 & & & & \\
\hline & & & & & & average & 0.707313 & 7 & 118.4 & 119.1 & 119.9 \\
\hline \multirow[t]{4}{*}{ Tobenna } & TB $2.5 \mathrm{~A}^{*}$ & requienid & 544 & 2732 & 181 & 19.2 & 0.707335 & & & & \\
\hline & TB $2.5 \mathrm{~B}$ & requienid & 832 & 1906 & 85.4 & 9.6 & 0.707327 & & & & \\
\hline & TB $2.5 \mathrm{C}$ & requienid & 956 & 2052 & 81.7 & 8.5 & 0.707319 & & & & \\
\hline & & & & & & average & 0.707323 & 7 & 119.1 & 119.9 & 120.7 \\
\hline \multirow[t]{4}{*}{ Coccovello } & $\mathrm{CO} 5.8 \mathrm{~A}$ & requienid & 1012 & 1172 & $<0.5$ & 2.3 & 0.707375 & & & & \\
\hline & $\mathrm{CO} 5.8 \mathrm{C}$ & requienid & 929 & 1036 & 32.7 & 3.2 & 0.707362 & & & & \\
\hline & CO $5.8 \mathrm{~B}$ & requienid & 848 & 1008 & 66.5 & 7.4 & 0.707382 & & & & \\
\hline & & & & & & average & 0.707373 & 12 & 122.1 & 122.9 & 123.5 \\
\hline \multirow[t]{4}{*}{ Croce } & CR 57.4 A & requienid & 1148 & 1920 & 94.4 & 2.4 & 0.707388 & & & & \\
\hline & CR 57.4 B & requienid & 1289 & 1702 & 4.0 & 0.8 & 0.707429 & & & & \\
\hline & CR 57.4 C & requienid & 1411 & 1967 & 110.5 & 0.0 & 0.707393 & & & & \\
\hline & & & & & & average & 0.707403 & 26 & 122.9 & 124.1 & 125.2 \\
\hline
\end{tabular}

Numerical age from McArthur et al. (2001, look-up table version 4: 08/04) calculated by combining the statistical uncertainty of the mean of the isotopic values with the uncertainty of the seawater curve. *: diagenetically altered sample.

the Mt. Tobenna section, are seemingly due to vadose diagenesis.

Summing up, the effects of diagenesis are certainly seen in the isotopic records of the studied successions. They are probably responsible for some high-frequency fluctuations, defined by one or a few data points, but they are not so pervasive as to distort completely the pristine marine signal.

The scatter plots of carbon and oxygen isotope ratios show also that there is no clear separation between the data points of the different lithofacies associations (Fig. 13). This suggests that variations in $\delta^{13} \mathrm{C}$ are not the result of facies changes. The bias of local palaeoenvironmental conditions could have been partly counteracted by the fact that micrite, or the micritic matrix in case of grainy facies, were analyzed instead of bulk samples. On the other hand, the lack of a strict relationship between facies type and $\delta^{13} \mathrm{C}$ has been observed also in the recent sediments of the Great Bahama Bank (Swart et al., 2009).

With the exception of Mt. Coccovello, the $\delta^{13} \mathrm{C}$ and $\delta^{18} \mathrm{O}$ mean values of the studied sections fall within the range of Barremian-Aptian seawater (taken from the "low-latitude" biotic calcite record of Prokoph et al., 2008) (Fig. 14, Table 4). Apart from Mt. Raggeto, whose samples plot almost entirely in the field of pristine Barremian-Aptian calcite, a tail of more depleted values is observed in all the other sections and especially for the Mt. Tobenna and Mt. Coccovello sections (Fig. 13). This pattern conforms to the facies distribution, indicating that Mt. Raggeto is the most open marine among the studied sections, followed by Mt. Croce. The other sections show more restricted facies and were located in a more inner platform position. A similar pattern of more negative values in the most restricted sections has been observed also in the Cenomanian-Turonian platform carbonates of the Apenninic platform (Parente et al., 2007).

The smoothed $\delta^{13} \mathrm{C}$ curves of figures 8 to 12 show that, besides the higher order fluctuations at metric to sub-metric scale, defined by only one or a few points, there are some isotopic trends and excursions which are defined by many data points and extend across intervals that are tens of metres thick. These major features of the $\delta^{13} \mathrm{C}$ curves are statistically significant because, at least in the Mt. Raggeto, Mt. Croce and Mt. Motola sections, they represent deviations from the mean value that are 2-3 times the standard deviation. Moreover, they persist across changes of lithofacies association, suggesting that they are not caused by local changes of palaeoenvironmental conditions. Finally, as discussed in the next paragraph, the major trends and excursions can be correlated between the five studied sections, suggesting that the forcing was, if not global, at least regional.

\subsection{The problem of gaps in the carbon isotope stratigraphy of carbonate platforms}

The stratigraphic archive has been described as containing more gaps than record (Ager, 1993). This is particularly true of shallow-water carbonate platforms whose record is typically characterized by shallowing-upward cycles truncated by subaerial exposure surfaces. Shallowing-up sequences can be created by progradation or migration of sedimentary 

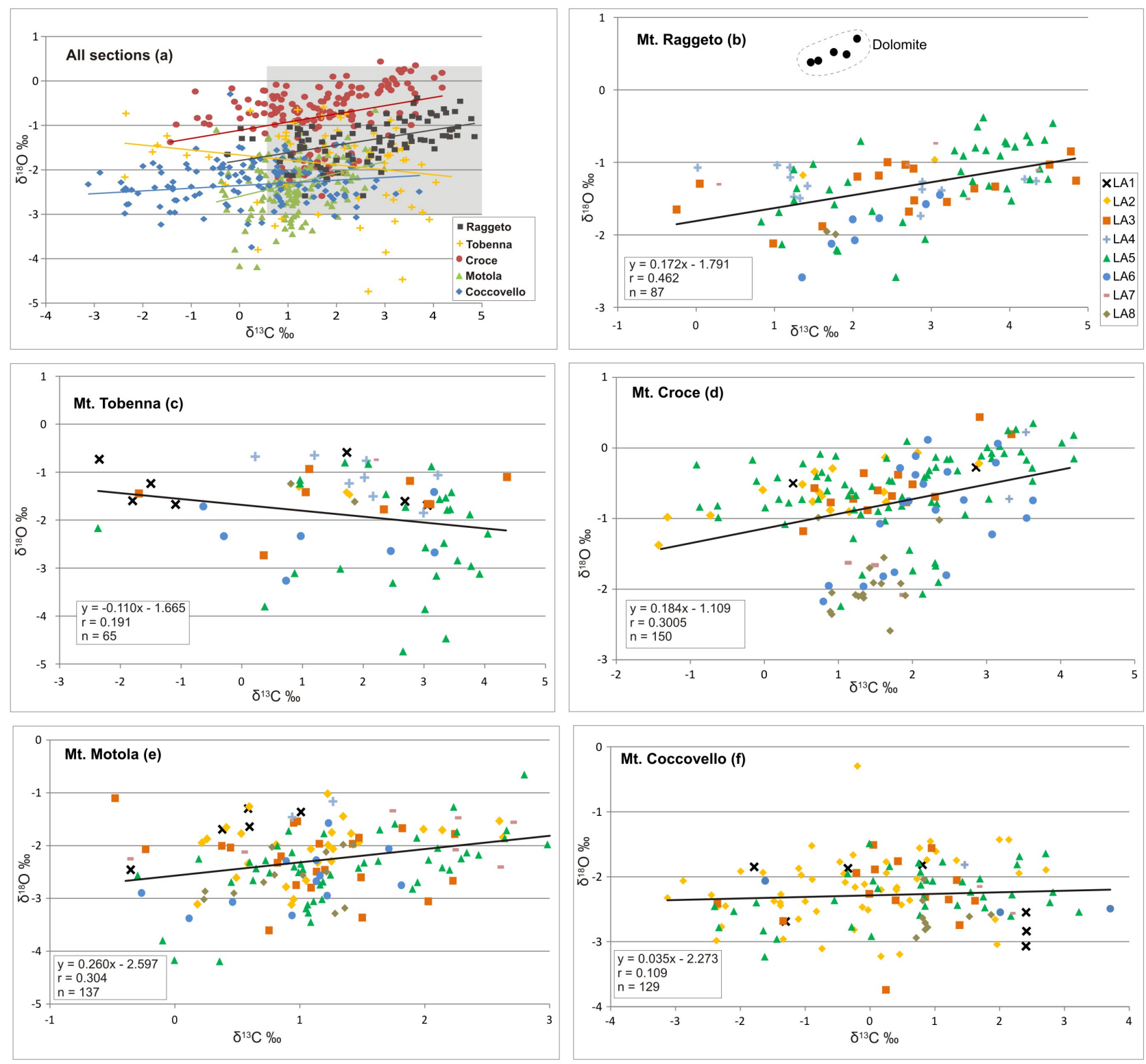

Fig. 13. Cross-plots of $\delta^{13} \mathrm{C}$ vs. $\delta^{18} \mathrm{O}$ for the whole dataset (a) and for each studied section (b-f). The all-lithofacies dataset (a) shows very low to moderate covariance $(r=0.01-0.46)$. Supratidal and intertidal lithofacies associations show higher covariance of stable isotope ratios (diagrams b-c; see also Table 3. On the other hand, there is no clear relation between lithofacies and isotopic value. The shaded rectangle in diagram (a) indicates the range of well-preserved biotic calcite of shallow marine tropical-subtropical carbonates (from Prokoph et al., 2008).

systems (e.g., Ginsburg, 1971; Pratt and James, 1986) but in many cases they are best interpreted as formed during one cycle of sea-level change (Strasser, 1991; Strasser et al., 1999). After emersion, a certain lag time elapses before prolific benthic carbonate production catches up (Tipper, 1997). As a result, shallowing upward cycles are expected to be asymmetric, with a thin transgressive deposit (including a lag) and a thicker highstand deposit (Strasser et al., 1999). High frequency cyclicity is generally superimposed on longer term cycles of sea-level changes. In simple "fully allocyclic" models, amplitude and duration of sea-level changes, together with subsidence rate, govern the thickness of elementary cycles, the duration of gaps and the distribution of "missed beats" in the different parts of the longer term cycle (Sadler, 1994). Thinner cycles and longer gaps, corresponding to missing elementary cycles, are expected during large scale lowstands. Conversely, thickest beds and shortest gaps are expected during large scale maximum flooding (Strasser et 


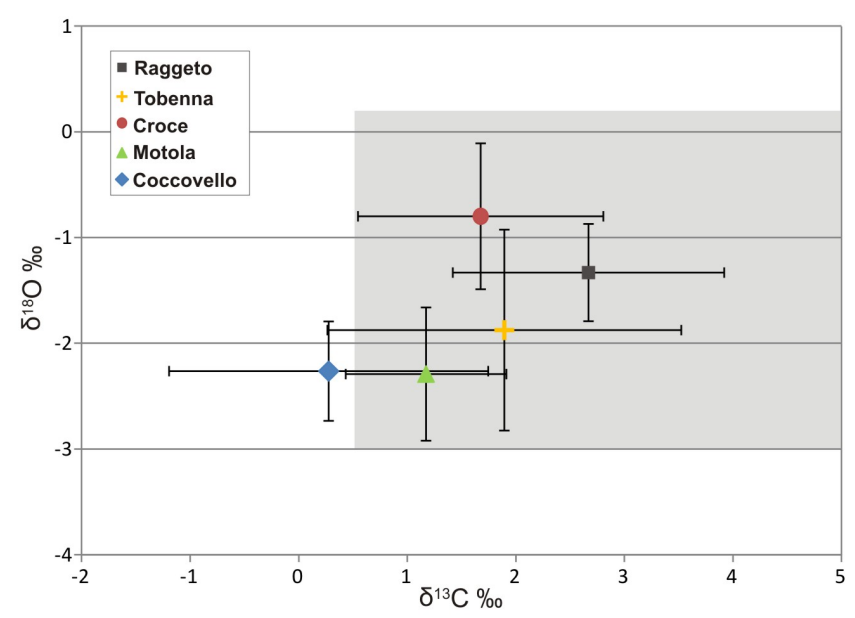

Fig. 14. Plot of the mean \pm standard deviation of carbon and oxygen isotope ratios for each studied section. With the exception of Mt. Coccovello, the $\delta^{13} \mathrm{C}$ and $\delta^{18} \mathrm{O}$ mean values of the studied sections fall within the range of Barremian-Aptian seawater, represented by the "low-latitude" biotic calcite record of Prokoph et al. (2008).

al., 1999). More complex distribution of gaps is obtained if stochastic models of carbonate production, transport, and deposition are applied (Burgess and Wright, 2003).

The presence of gaps can severely hamper the interpretation of the carbon isotope curves of carbonate platform sections. If elementary cycles represent precession cycles, any feature in the target $\delta^{13} \mathrm{C}$ curve of the deep-water reference sections which lasts less than $20 \mathrm{ky}$ will have few, if any, chances of being recorded, due to the pervasive distribution of gaps at this timescale. Missed beats will conceal even longer traits of the target curve, especially during long term lowstands, expressed in the rock record as higher order sequence boundary zones (Strasser et al., 2000).

A Milankovitch cyclicity has been inferred for the shallow-water Barremian-Aptian carbonates of the ACP (D'Argenio et al., 2004 and references therein). A $20 \mathrm{ky}$ duration, corresponding to the precession cycle, has been inferred for the elementary cycles. Higher order cycles, expressed as bundles and superbundles of elementary cycles, have been interpreted as controlled respectively by the $100 \mathrm{ky}$ and $400 \mathrm{ky}$ eccentricity cycle. Based on high resolution cyclostratigraphic correlation with the Serra Sbregavitelli section, showing the most open marine record, many missed beats were identified in the other sections at the cycle, bundle and superbundle scale. The longest inferred gaps are of about $500 \mathrm{ky}$ in the Mt. Raggeto section and up to $1 \mathrm{my}$ in the Mt. Tobenna-Mt. Faito composite section (see Fig. 8 in D'Argenio et al., 2004). Such very long gaps may potentially hide also the major features of the reference $\delta^{13} \mathrm{C}$ curve, considering that a duration of about 1.2 my has been estimated for the rising limb (stages C4-C6) of the positive
Table 3. Statistical results for $\mathrm{C}$ and $\mathrm{O}$ isotopes covariation in the studied sections

\begin{tabular}{|c|c|c|c|c|c|}
\hline Section & LA & $n$ & $r$ & $a$ & $b$ \\
\hline \multirow{9}{*}{ Raggeto } & LA1 & 0 & $*$ & $*$ & $*$ \\
\hline & LA2 & 2 & $*$ & $*$ & $*$ \\
\hline & LA3 & 17 & 0.51 & 0.12 & -1.66 \\
\hline & LA4 & 13 & 0.30 & -0.04 & -1.20 \\
\hline & LA5 & 40 & 0.57 & 0.26 & -2.02 \\
\hline & LA6 & 7 & 0.93 & 0.56 & -3.16 \\
\hline & LA7 & 6 & 0.15 & 0.02 & -1.23 \\
\hline & LA8 & 2 & $*$ & $*$ & $*$ \\
\hline & ALL & 87 & 0.46 & 0.17 & -1.80 \\
\hline \multirow{9}{*}{ Tobenna } & LA1 & 7 & 0.19 & -0.04 & -1.29 \\
\hline & LA2 & 3 & $*$ & & $*$ \\
\hline & LA3 & 9 & 0.24 & 0.07 & -1.67 \\
\hline & LA4 & 8 & 0.65 & -0.28 & -0.54 \\
\hline & LA5 & 28 & 0.06 & -0.05 & -2.22 \\
\hline & LA6 & 7 & 0.01 & 0.00 & -2.34 \\
\hline & LA7 & 1 & $*$ & $*$ & $*$ \\
\hline & LA8 & 2 & $*$ & $*$ & $*$ \\
\hline & ALL & 65 & 0.19 & -0.11 & -1.66 \\
\hline \multirow{9}{*}{ Croce } & LA1 & 2 & $*$ & $*$ & $*$ \\
\hline & LA2 & 17 & 0.74 & 0.22 & 0.8 \\
\hline & LA3 & 14 & 0.78 & 0.41 & -1.22 \\
\hline & LA4 & 2 & $*$ & $*$ & $*$ \\
\hline & LA5 & 73 & 0.31 & 0.14 & -0.83 \\
\hline & LA6 & 22 & 0.52 & 0.48 & -1.97 \\
\hline & LA7 & 3 & $*$ & $*$ & $*$ \\
\hline & LA8 & 17 & 0.21 & 0.22 & -2.24 \\
\hline & ALL & 150 & 0.30 & 0.18 & -1.11 \\
\hline \multirow{9}{*}{ Motola } & LA1 & 5 & 0.93 & 0.86 & -2.07 \\
\hline & LA2 & 27 & 0.33 & 0.28 & -2.36 \\
\hline & LA3 & 22 & 0.29 & -0.26 & -1.98 \\
\hline & LA4 & 2 & $*$ & $*$ & $*$ \\
\hline & LA5 & 49 & 0.6 & 0.5 & -3.11 \\
\hline & LA6 & 12 & 0.5 & 0.44 & -3.07 \\
\hline & LA7 & 7 & 0.35 & 0.13 & -2.1 \\
\hline & LA8 & 13 & 0.34 & 0.36 & -2.93 \\
\hline & ALL & 137 & 0.30 & 0.26 & -2.6 \\
\hline \multirow{9}{*}{ Coccovello } & LA1 & 7 & 0.59 & -0.17 & -2.27 \\
\hline & LA2 & 54 & 0.25 & 0.1 & -2.15 \\
\hline & LA3 & 15 & 0.08 & 0.04 & -2.28 \\
\hline & LA4 & 1 & $*$ & $*$ & $*$ \\
\hline & LA5 & 38 & 0.43 & 0.11 & -2.35 \\
\hline & LA6 & 3 & $*$ & $*$ & $*$ \\
\hline & LA7 & 2 & $*$ & $*$ & $*$ \\
\hline & LA8 & 9 & 0.05 & 0.03 & -2.64 \\
\hline & ALL & 129 & 0.01 & 0.03 & -2.27 \\
\hline
\end{tabular}

LA $=$ lithofacies association; $n=$ number of observations; $r=$ Pearson correlation coefficient; $a=$ slope of the regression line; $b=$ intercept of the regression line; $*$ not calculated when $n<5$. 
Table 4. Mean and Standard deviation for carbon and oxygen isotope ratios of the studied sections

\begin{tabular}{lll}
\hline \multirow{2}{*}{ Section } & \multicolumn{2}{c}{ MEAN \pm STDEV } \\
\cline { 2 - 3 } & $\delta^{13} \mathrm{C} \%$ c & $\delta^{18} \mathrm{O} \%$ \\
\hline Raggeto & $2.67 \pm 1.25$ & $-1.33 \pm 0.46$ \\
Tobenna & $1.89 \pm 1.63$ & $-1.87 \pm 0.95$ \\
Croce & $1.67 \pm 1.13$ & $-0.79 \pm 0.69$ \\
Motola & $1.17 \pm 0.74$ & $-2.29 \pm 0.63$ \\
Coccovello & $0.27 \pm 1.47$ & $-2.26 \pm 0.47$ \\
\hline
\end{tabular}

CIE associated with the "Selli event" (Li et al., 2008; Malinverno et al., 2010).

\subsection{Platform-to-basin chemostratigraphic correlation}

Assuming that the carbon isotope record of the five studied sections was not shaped by local palaeoenvironmental changes and diagenetic overprint, a chemostratigraphic correlation was attempted with the reference carbon isotope curve of the Cismon Apticore in the southern Alps (Menegatti et al., 1998; Erba et al., 1999) and with the composite curve of Herrle et al. (2004) from the Vocontian Basin of south-eastern France. The nomenclature of the isotopic segments is taken from Wissler et al. (2003) for the Barremian-Early Aptian interval (B3-B8/A1-A3) and from Menegatti et al. (1998) for the isotopic excursion of the Selli event (C3-C7) (Fig. 15).

A correlation between the carbon isotope curves of the studied sections is possible by using as tie points the last occurrence of $P$. lenticularis, the two acmes of $S$. dinarica, the "Orbitolina level" and the A. reicheli level. At Mt. Raggeto there are three positive $\delta^{13} \mathrm{C}$ excursions at values $>+3-4 \%$ o between the "Palorbitolina limestones" and the FO of $A$. reicheli. The first excursion is rather short (it takes less than $10 \mathrm{~m}$ ) and peaks a few metres above the last occurrence of P. lenticularis. A positive excursion of similar shape and amplitude, occurring in the same stratigraphic position, is observed also at Mt. Croce and at Mt. Coccovello. At Mt. Motola this positive excursion is seemingly truncated by a small gap, because there is only a minor positive peak at about $+1 \%$, nearly corresponding with the LO of $P$. lenticularis. The Mt. Tobenna section starts above the LO of P. lenticularis and this first excursion is probably represented only by the small peak at $+3 \%$ occurring at the base of the section.

The first positive excursion of the Mt. Raggeto curve is here correlated with the A1-A2 segments of Wissler et al. (2003). This correlation is supported by the SIS numerical age of $124.1 \pm 1.1 \mathrm{Ma}$, corresponding to the D. oglanlensis ammonite zone, of the requienid level occurring $3 \mathrm{~m}$ below the LO of $P$. lenticularis at Mt. Croce. This is in agreement with the correlation of the Mt. Raggeto curve of Wissler et al. (2004) and is further supported by their magnetostratigraphic data, placing the M0 within superbundle R14, which corresponds to the top of the "Palorbitolina limestones" (Amodio et al., 2003). Accordingly, the distinctive negative trend preceding this positive excursion in the Mt. Croce, Mt. Motola and Mt. Coccovello sections can be correlated to the B7-B8 segments of Wissler et al. (2003). Chemostratigraphic correlation becomes less compelling for the lower part of these sections, mainly because of the lack of independent tie-points and because of the small amplitude of isotopic excursions in the reference curves $(<1 \%$ ). Nevertheless, a tentative correlation is supplied in Fig. 15, which suggests that the lowermost part of the Mt. Motola and Mt. Coccovello sections might extend into the Early Barremian.

The second positive excursion of the Mt. Raggeto curve is much broader (nearly $30-40 \mathrm{~m}$ ). It starts some $10 \mathrm{~m}$ above the LO of P. lenticularis, peaks at $+4.9 \%$ at a level corresponding to the first acme of $S$. dinarica, and finishes with values close to $0 \%$ a few $\mathrm{m}$ below the second acme of S. dinarica. This second positive excursion is completely missing at Mt. Motola. In the other sections the rising limb and the peak interval (corresponding to values above $+4 \%$ ) are largely missing, while the decreasing limb is at least partly recorded in the Mt. Tobenna and Mt. Coccovello section, less in the Mt. Croce section. In these three sections the "Orbitolina level" occurs in what is left of the decreasing limb of this positive excursion. In agreement with Wissler et al. (2004; see also Ferreri et al., 1997) this second positive excursion is correlated with the positive CIE associated with the "Selli event". This correlation is also supported by the SIS ages of $119.9 \mathrm{Ma}$ for a requienid bed $5.8 \mathrm{~m}$ below the "Orbitolina level" at Mt. Tobenna and of 119.2 Ma for a level immediately below the second acme of $S$. dinarica at Mt. Motola (Fig. 15 and Table 2). On the contrary, this correlation is at odds with the SIS age of $122.9 \mathrm{Ma}$ obtained for a requienid level occurring $1 \mathrm{~m}$ above the first marls with Mesorbitolina at Mt. Coccovello (Fig. 15 and Table 2).

The third positive excursion of the Mt. Raggeto curve starts a few metres below the second acme of $S$. dinarica, peaks at about $4.5 \%$ and decreases to values $<0 \%$ at the top of the section, close to the FO of $A$. reicheli. This positive excursion is well expressed in all the other sections but at Mt. Coccovello, where its rising limb and peak interval are truncated by a gap, whose occurrence is supported also by the truncated range of $S$. dinarica just above its second acme (Fig. 15). The correlation of this excursion with the reference curve is more problematic. It could correspond to the broad positive excursion spanning the P. melchioris, $N$. nolani and the lower part of the $H$ jacobi ammonite zones in the composite $\delta^{13} \mathrm{C}$ curve of the Vocontian basin (Herrle et al., 2004; Föllmi et al., 2006). Alternatively, it could embrace also the positive excursion spanning the Aptian-Albian boundary.

The chemostratigraphic correlation proposed above differs from the one proposed in previous works, when the 

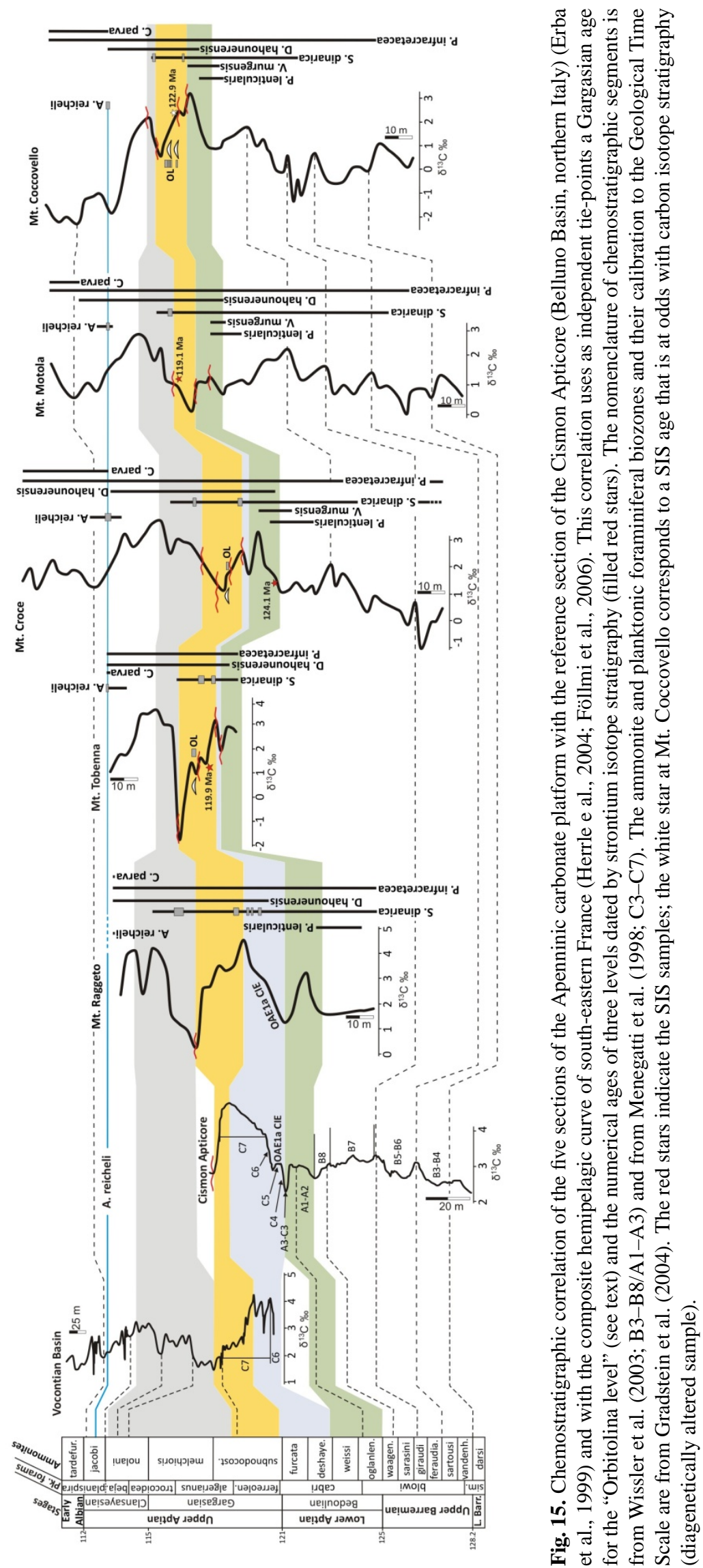
more complete Mt. Raggeto section was not yet included in the database (Di Lucia and Parente, 2008; Di Lucia, 2009). In particular, since the most prominent positive excursion, which is fully recorded only at Mt. Raggeto, was at least partly missed in a gap in the other sections, the next positive excursion (the one starting above the "Orbitolina level") was misidentified as the Selli event excursion. This mistake stemmed from the impossibility of estimating correctly the duration of gaps, which are below biostratigraphic resolution, without making reference to a more complete section and with very few independent points of chronostratigraphic calibration (like SIS data or well dated biostratigraphic markers). This highlights once more the difficulty of applying carbon isotope stratigraphy in inherently incomplete and poorly dated shallow-water carbonate platform sections.

\subsection{Biostratigraphic criteria for the Selli event in central Tethyan carbonate platforms}

Chemostratigraphic correlation with the well dated carbon isotope curves of the Cismon core and of the Vocontian composite section allows individuating in the carbonate platform successions of the southern Apennines the segments corresponding to the OAE1a and to propose a set of biostratigraphic criteria to individuate the stratigraphic interval equivalent to the OAE1a in the carbonate platforms of the central and southern Tethys. These criteria will be particularly useful when carbon isotope stratigraphy is not available or when chemostratigraphic correlation is biased by low resolution or by the overprint of local palaeoceanographic processes and/or of early meteoric diagenesis. A survey of the recent literature shows that this is often the case in shallowwater carbonate sections. For instance, some recently published carbon isotope curves from the Barremian-Aptian of the Adriatic-Dinaric carbonate platform show no evidence of the broad positive excursion associated with the Selli event and of the preceding negative shift (Tešović et al., 2011). In another case study, the OAE1a positive CIE is not present in the carbon isotope record of bulk/micritic matrix samples, while it is more faithfully reproduced by the biotic calcite of rudist shells (Huck et al., 2010).

Based on the chemostratigraphic correlation of Fig. 15, the segment of decreasing $\delta^{13} \mathrm{C}$ values leading to the $\mathrm{C} 3$ negative peak, which is taken as the onset of the Selli event, starts a few metres above the LO of P. lenticularis and V. murgensis. The C4-C6 segments, corresponding to the interval of enhanced accumulation of organic matter in deep-water sections, ends just below the first acme of $S$. dinarica, which roughly corresponds to the $\mathrm{C} 7$ segment of peak $\delta^{13} \mathrm{C}$ values. The whole CIE associated with the OAE1a is bracketed in the ACP between the LO of V. murgensis and the "Orbitolina level".

These criteria are particularly useful because they are based on biostratigraphic events that are widely employed in the most popular biostratigraphic schemes of central and southern Tethyan carbonate platforms (Velić, 2007; Chiocchini et al., 2008). In particular, the acme of $S$. dinarica is easily picked in the field and is widely recognized in central Tethyan carbonate platforms (Carras et al., 2006 and references therein; Velić, 2007). The "Orbitolina level", containing $M$. parva and M. texana, has long been used as a biolithostratigraphic marker in the geological maps of southern Apennines.

\subsection{Chronostratigraphic calibration of carbonate platform biostratigraphy}

The biozonations of the Lower Cretaceous carbonate platforms of the central Tethys (Apenninic, Adriatic and Gavrovo-Tripolitza platforms) are mainly based on calcareous algae and larger benthic foraminifera. The chronostratigraphic calibration of these schemes has always posed serious problems because ammonites, and calcareous plankton and nannoplankton, which are the pillars of Cretaceous chronostratigraphy, are notably absent from carbonate platform successions.

The problem of chronostratigraphic calibration has been explicitly acknowledged by some authors (De Castro, 1991; Chiocchini et al., 2008). Others (Bachmann and Hirsch, 2006; Velić, 2007) have anchored their biostratigraphic schemes to the chronostratigraphic ages of orbitolinid larger foraminifera, which have been established mainly in Northern Tethyan carbonate platforms.

Several shortcomings in this indirect correlation are highlighted below:

- The precise isochrony of FOs and LOs of orbitolinid species between the northern and central-southern carbonate platforms has been never tested against independent evidence.

- Orbitolinids are generally found in discrete intervals and sometimes are totally lacking in inner platform facies. Namely, the flat low-conical species are generally found in marly or calcareous marly levels, which seemingly represent transgressive to maximum flooding intervals (Vilas et al., 1995; Immenhauser et al., 1999; Jones et al., 2004). The local range of these taxa could be related more to the occurrence of the appropriate facies, controlled by local to regional sea-level history, than to evolutionary processes of speciation and extinction.

- The chronostratigraphic calibration of orbitolinid biostratigraphy is still the matter of intense scientific debate, even in the areas where it has been first proposed, like the Urgonian Platform of the northern Tethyan margin (Arnaud et al., 1998; Clavel et al., 2007; Föllmi, 2008; Conrad et al., 2011; Godét et al., 2011; Huck et al., 2011). 
For all these reasons, the supremacy of chemostratigraphic correlation is advocated to establishing the chronostratigraphic calibration of carbonate platform biostratigraphy.

The chemostratigraphic correlation with the well-dated reference sections of the Cismon Apticore and of the Vocontian basin of south-eastern France is here used to establishing the chronostratigraphic age of the biostratigraphic events recognized in the carbonate platform successions of the southern Apennines (Fig. 15). The lowest FO and the highest LO are considered, assuming that the small differences between the ranges observed in the three studied sections are the result of the lack of appropriate facies, of small gaps or of other sampling biases.

- The FO of $P$. infracretacea correlates with the lowermost Upper Barremian (H. sartousi ammonite zone). This species persists until the top of the five studied sections.

- The range of $P$. lenticularis spans from the uppermost Barremian (P. waagenoides zone) to the lowermost Aptian (upper part of the D. oglanlensis zone). In the studied sections the levels rich of P. lenticularis (LA8, "Palorbitolina limestones") mark a transgressive interval corresponding to the B8-A1 segments of the carbon isotope curves. Therefore, chemostratigraphy supports a correlation of the "Palorbitolina limestones" of southern Apennines with the "Couches inférieures à Orbitolines" of the French Vercors and with the "Lower Orbitolina Beds" of the northern Tethyan Helvetic platform (Arnaud et al., 1998; Clavel et al., 2002; Föllmi et al., 2007; Föllmi and Gainon, 2008).

- The range of $V$. murgensis straddles the BarremianAptian boundary (FO in the upper part of the $P$. waagenoides zone, LO in the lower part of the D. weissi zone).

- The FO of D. hahounerensis is close to the base of the Aptian (D. oglanlensis ammonite zone). The LO correlates with the Upper Aptian H. jacobi ammonite zone.

- The first acme of $S$. dinarica begins in latest Early Aptian (D. furcata zone) and straddles the BedoulianGargasian boundary, terminating in the lower part of the E. subnodosocostatum zone. The second acme is roughly correlated with the lowermost part of the P. melchioris zone. The LO can be correlated with the upper part of the N. nolani ammonite zone.

- The "Orbitolina level" of the southern Apennines, containing an association of M. parva and M. texana, correlates with the upper part of the E. subnodosocostatum zone, confirming the middle Gargasian age proposed by Cherchi et al. (1978). A Gargasian age for the FO of $M$. texana, has been recently restated by Schroeder et al. (2010), and remains one of the tie points for the calibration of the Aptian biostratigraphy of central and southern Tethyan carbonate platforms (Simmons, 1994; Witt and Gökdağ, 1994; Bachmann and Hirsch, 2006; Velić, 2007). However, it is worth noting that in the northern Tethyan Helvetic carbonate platform M. texana has been found in the upper Schrattenkalk Fm. (Schroeder in Schenk, 1992; Schroeder et al., 2007), which has been dated by carbon isotope stratigraphy and ammonites as middle Early Aptian, close to the boundary between the $D$. weissi and the $D$. deshayesi zones (Föllmi, 2008; Föllmi and Gainon, 2008). The "Orbitolina level" of the southern Apennines cannot be correlated with the "Couches superieures à orbitolines" of the French Vercors and the "Upper Orbitolina Beds" of the Helvetic Alps (Linder et al., 2006; Föllmi and Gainon, 2008). Instead, a correlation with the "Niveau Fallot" of the Vocontian Basin (Friedrich et al., 2003), recently proposed by Raspini (2011), is compatible with the chemostratigraphic data presented here.

- The A. reicheli level, consisting of a bed rich of fully developed specimens of this alveolinid species, is correlated with the middle part of the $H$. jacobi zone (Upper Aptian). In the Mt. Motola, Mt. Tobenna and Mt. Croce section this level is preceded by some metres of limestones with a few small primitive specimens of $A$. reicheli.

- The FO of C. parva is correlated with the middle part of the H. jacobi zone, in the Upper Aptian.

In the scheme of Fig. 16, the chronostratigraphic ranges supported by the chemostratigraphic correlation presented in this paper are compared with the ranges given for the same species in other biostratigraphic schemes of central and southern Tethyan carbonate platforms (Bachmann and Hirsch, 2006; Husinec and Sokač, 2006; Velić, 2007; Chiocchini et al., 2008; Tešović et al., 2011).

Some discrepancies emerge, which might be at least partly due to a slight diachrony of the biostratigraphic events between different carbonate platforms. However, it must be reemphasized that the chronostratigraphic calibration proposed in this paper is the first direct calibration based on isotope stratigraphy. For all the other biostratigraphic schemes cited above, the chronostratigraphic calibration is largely based on the ages proposed for orbitolinids in the carbonate platforms of the Northern Tethyan margin. This indirect chronostratigraphic calibration might be biased for several reasons, as discussed above.

\section{Conclusions}

The geological archive of the resilient central and southern Tethyan carbonate platforms contains valuable information on the response of tropical and subtropical neritic ecosystems 


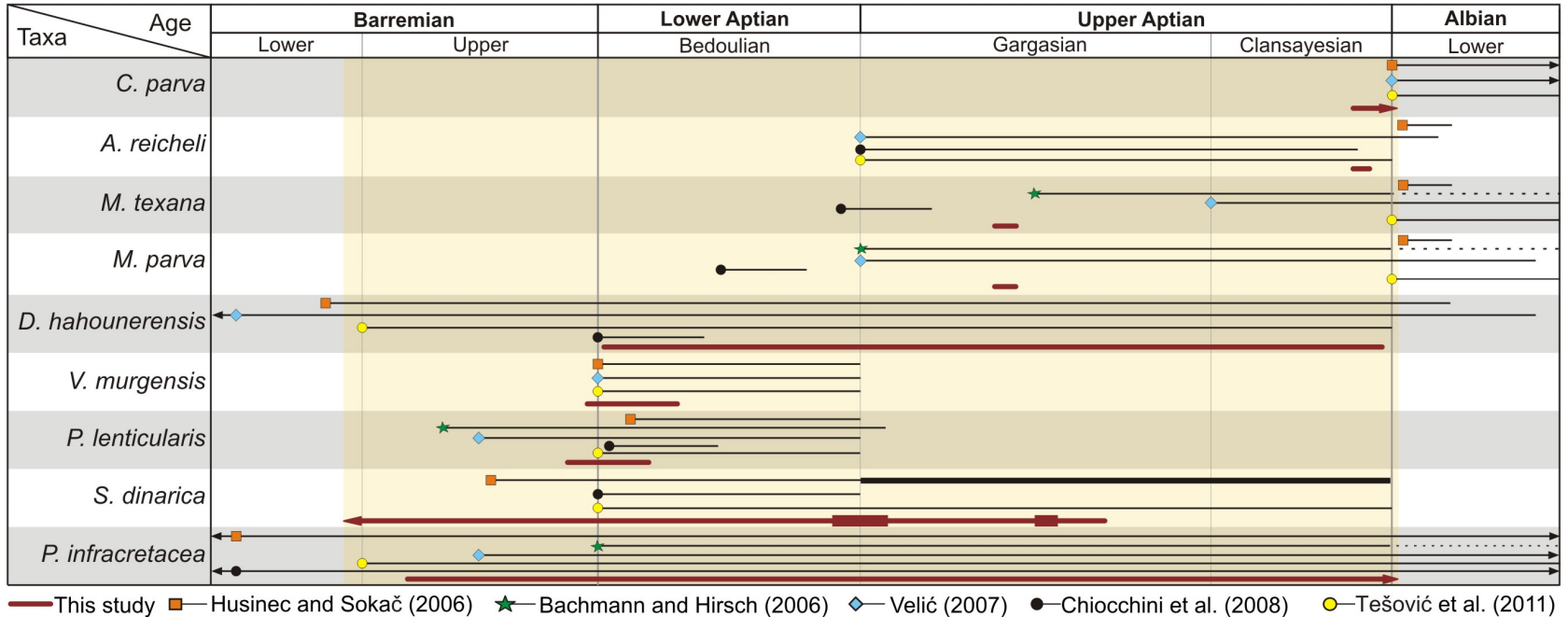

Fig. 16. Chronostratigraphic calibration of the Apenninic carbonate platform biostratigraphy. The calibration is based on the chemostratigraphic correlation with well-dated basinal sections (see Fig. 15). The chronostratigraphic calibration of the same biostratigraphic events, proposed by previous works on the Apenninic and other central and southern Tethyan carbonate platforms, is given for comparison. The shaded field indicates the chronostratigraphic interval covered by the sections studied in this paper.

to the palaeoenvironmental perturbations associated with the massive injection of $\mathrm{CO}_{2}$ into the Atmosphere-Ocean system during the early Aptian OAE1a. The first step to unlock this archive is to increase the precision of chronostratigraphic dating and correlation of shallow-water carbonate successions with deep-water successions, which represent the reference record of palaeoceanographic events. In this paper this task is fulfilled by integrating carbon isotope stratigraphy and biostratigraphy, with additional support by strontium isotope stratigraphy on a limited set of samples. Chemostratigraphic correlation of five sections of the Apenninic carbonate platform of southern Italy with the Cismon Apticore and the composite section of the Vocontian Basin permits the chronostratigraphic calibration of carbonate platform biostratigraphy across the Barremian-Aptian interval.

The main result derived from this calibration is the definition of biostratigraphic criteria to individuate, in the carbonate platforms of the central and southern Tethys, the stratigraphic interval equivalent to the OAE1a. The interval of decreasing $\delta^{13} \mathrm{C}$ values preceding the $\mathrm{C} 3$ negative peak, which marks the onset of the Selli event, starts a few metres above the LO of $P$. lenticularis and just above the LO of V. murgensis. The C4-C6 segments, which correspond in deep-water sections to the interval of black shales deposition, ends just below the first acme of $S$. dinarica. The second acme of this species roughly corresponds to the $\mathrm{C} 7$ segment of peak $\delta^{13} \mathrm{C}$ values. The "Orbitolina level" marks the return the preexcursion values at the end of the broad positive CIE associated with the OAE1a.

Another valuable result is the definition of a biostratigraphic criterion to spike the Barremian-Aptian boundary in central-southern Tethyan carbonate platforms. According to the calibration proposed in this paper, the boundary is very closely approximated by the first occurrence of $V$. murgensis and D. hahounerensis.

In all the biostratigraphic schemes published so far for the Apenninic carbonate platform and other central and southern Tethyan platforms, the chronostratigraphic calibration was anchored to the ages established for selected taxa of orbitolinid foraminifera in the carbonate platform of the Northern Tethyan margin. This is the first chronostratigraphic calibration, for the Apenninic carbonate platform, constrained by carbon and strontium isotope stratigraphy. Chemostratigraphy is being successfully applied to Cretaceous carbonate platforms. Its integration with biostratigraphy hold the promise of producing standard biozonations, based on larger foraminifera and calcareous algae, perfectly tied to the chronostratigraphic scale. This would open the possibility of fully exploiting the valuable archive of palaeoenvironmental changes preserved by Cretaceous carbonate platforms.

Acknowledgements. We gratefully acknowledge D. Buhl, U. Schulte and B. Grechen for taking care of our samples at the Isotopen-labor of the Institut für Geologie, Mineralogie und Geophysik at the Ruhr University (Bochum, Germany). Solid Earth reviewers K. Föllmi, A. Immenhauser and H. Weissert greatly contributed to improve the first version of our manuscript with their constructive criticism. We are also grateful to the guest editors J. Trabucho-Alexandre and D. Gröcke for their assistance and advice. G. Frijia is warmly acknowledged for his suggestions on chemostratigraphic dating and correlation. MP was supported by a Regione Campania LR5/05 grant. MDL and AT were partly supported by postgraduate IAS grants during their $\mathrm{PhD}$ work at the University of Naples. AT was also supported by a postgraduate 
grant from the Italian Association for Sedimentary Geology (GEOSED).

Special Issue: "Phanerozoic black shales and oceanic anoxic events: geochemistry, sedimentology and stratigraphy"

Edited by: J. Trabucho-Alexandre, P. L. de Boer, and D. R. Gröcke

\section{References}

Ager, D. V.: The Nature of the Stratigraphical Record, 3 Edn., 151 pp., John Wiley \& Sons, 1993.

Allan, J. R. and Matthews, R. K.: Isotope signature associated with early meteoric diagenesis, Sedimentology, 29, 797-897, 1982.

Amodio, S., Buonocunto, F. P., D’Argenio, B., Ferreri, V., and Gorla, L.: Cyclostratigraphy of Cretaceous shallow-water carbonates, Case histories from central and southern Italy, AAPG Search and Discovery Article, \#90017, 2003.

Arnaud, H., Arnaud-Vanneau, A., Blanc-Alétru, M.-C., Adatte, T., Argot, M., Delanoy, G., Thieuloy, J.-P., Vermeulen, J., Virgone, A., Virlouvet, B., and Wermeille, S.: Répartition stratigraphique des orbitolinidés de la plate-forme urgonienne subalpine et jurassiene (SE de la France), Géologie Alpine, 74, 3-89, 1998.

Arthur, M. A., Brumsack, H.-J., Jenkyns, H. C., and Schlanger, S. O.: Stratigraphy, geochemistry, and paleoceanography of organic carbon-rich Cretaceous sequences, in: Cretaceous Resources, Events and Rhythms, edited by: Ginsburg, N. and Baudoin, B., Kluwer, Dordrecht, 75-119, 1990.

Bachmann, M. and Hirsch, F.: Lower Cretaceous carbonate platform of the eastern Levant (Galilee and the Golan Heights): stratigraphy and second-order sea-level change, Cret. Res., 27, 487-512, 2006.

Bonardi, G., D’Argenio, B., and Perrone, V.: Carta Geologica dell'Appennino meridionale, SELCA, Firenze, 1988.

Bosellini, A.: Dinosaurs "re-write" the geodynamics of the eastern Mediterranean and the paleogeography of the Apulia Platform, Earth Sci. Rev., 59, 211-234, 2002.

Buonocunto, F. P.: Litostratigrafia di alta risoluzione nel Cretacico di piattaforma Carbonatica dell'Appennino Campano: Ph.D. Thesis, Università Federico II, Napoli, 184, 1998.

Burgess, P. M. and Wright, V. P.: Numerical forward modelling of carbonate platform dynamics: An evaluation of complexity and completeness in carbonate strata, J. Sed.Res., 73, 637-652, 2003.

Burla, S., Heimhofer, U., Hochuli, P. A., Weissert, H., and Skelton, P.: Changes in sedimentary patterns of coastal and deep sea successions from the North Atlantic (Portugal) linked to Early Cretaceous environmental change, Palaeogeogr. Palaeocl., 257, 38-57, 2008.

Carannante, G., Graziano, R., Ruberti, D., and Simone, L.: Upper Cretaceous temperate-type open shelves from northern (Sardinia) and southern (Apennines-Apulia) Mesozoic Tethyan margins, in: Cool-water carbonates, edited by: James, N. P. and Clarke, J., SEPM Spec. P., 56, 309-325, 1997.

Carras, N., Conrad, M. A., and Radoičić, R: Salpingoporella, a common genus of Mesozoic Dasycladales (calcareous green algae), Rev. Paléobiol. 25, 457-517, 2006.
Cherchi, A., De Castro, P., and Schroeder, R.: Sull'etá dei livelli a Orbitolinidi della Campania e delle Murge Baresi (Italia meridionale), Boll. Soc. Nat., Napoli, 87, 363-385, 1978.

Chiocchini, M., Farinacci, A., Mancinelli, A., Molinari, V., and Potetti, M.: Biostratigrafia a foraminiferi, dasicladali e calpionelle delle successioni carbonatiche mesozoiche dell'Appennino centrale (Italia), Studi Geologici Camerti, Volume Speciale, 1994, "Biostratigrafia dell'Italia centrale", 9-129, 1994.

Chiocchini, M., Chiocchini, R. A., Didaskalou, P., and Potetti, M.: Microbiostratigrafia del Triassico superiore, Giurassico e Cretacico in facies di piattaforma carbonatica del Lazio centromeridionale e Abruzzo: revisione finale, Mem. Descr. Carta Geol. d' It., 5-170, 2008.

Clavel, B., Schroeder, R., Charollais, J., Busnardo, R., Martin Closas, C., Decrouez, D., Sauvagnat, J., and Cherchi, A.: Les "Couches inférieures à orbitolines" (Chaînes subalpines septentrionales): mythe ou réalité?, Revue de Paléobiologie, Genève, 21, 865-871, 2002.

Clavel, B., Charollais, J., Conrad, M., Jan du Chêne, R., Busnardo, R., Gardin, S., Erba, E., Schroeder, R., Cherchi, A., Decrouez, D., Granier, B., Sauvagnat, J., and Weidmann, M.: Dating and progradation of the Urgonian limestone from the Swiss Jura to southeast France, Zeitschrift der Deutschen Gesellschaft für Geowissenschaften, 158, 4, 1025-1062, 2007.

Colombié, C., Lécuyer, C., and Strasser, A.: Carbon- and oxygenisotope records of palaeoenvironmental and carbonate production changes in shallow-marine carbonates (Kimmeridgian, Swiss Jura), Geol. Mag., 148, 133-153, 2011.

Conrad, M., Clavel, B., Granier, B., Charollais, J., Busnardo, R., Erba, E., Gardin, S., Jan du Chêne, R., Decrouez, D., Cherchi, A., Schroeder, R., Sauvagnat, J., and Weidmann, M.: "Stratigraphic, sedimentological and palaeoenvironmental constraints on the rise of the Urgonian platform in the western Swiss Jura" by A. Godet et al. (2010) Sedimentology 57, 1088-1125: Discussion, Sedimentology, doi:10.1111/j.13653091.2011.01277.x, 2011.

D'Argenio, B. and Alvarez W.: Stratigraphic evidence for crustal thickness changes on the southern Tethyan margin during the Alpine cycle, GSA Bull., 91, 12, 681-689, 1980.

D’Argenio, B., De Castro, P., Emiliani, C., and Simone, L.: Bahamian and Apenninic limestones of identical lithofacies and age, AAPG Bull., 59, 524-533, 1975.

D’Argenio, B., Ferreri, V., Ardillo, F., and Buonocunto, F. P.: Microstratigrafia e stratigrafia sequenziale. Studi sui depositi di piattaforma carbonatica. Cretacico del Monte Maggiore (Appennino Meridionale, Boll. Soc. Geol. Ital., 112, 739-749, 1993.

D’Argenio, B., Ferreri, V., Iorio, M., Raspini, A., and Tarling, D. H.: Diagenesis and remanence acquisition in the Cretaceous carbonates of Monte Raggeto, Southern Italy, in: Palaeomagnetism and Diagenesis in Sediments, edited by: Tarling, D.H. and Turner, P., Geol. Soc. Lond., Spec. P., 151, 147-156, 1999a.

D’Argenio, B., Ferreri, V., Raspini, A., Amodio, S., and Buonocunto, F. P.: Cyclostratigraphy of a carbonate platform as a tool for high-precision correlation, Tectonophysics, 315, 357-385, 1999b.

D’Argenio, B., Ferreri, V., Weissert, H., Amodio, S., Buonocunto, F. P., and Wissler, L.: A multidisciplinary approach to global correlation and geochronology: the Cretaceous shallow-water car- 
bonates of southern Apennines, Italy, in: Cyclostratigraphy: Approaches and Case Histories, edited by: D'Argenio, B., Fischer, A.G., Premoli Silva I., Weissert, H. and Ferreri, V., SEPM Spec. P., 81, 103-122, 2004.

Davey, S. D. and Jenkyns, H. C.: Carbon-isotope stratigraphy of shallow-water limestones and implications for the timing of Late Cretaceous sea-level rise and anoxic events (CenomanianTuronian of the peri-Adriatic carbonate platform, Croatia), Eclogae Geol. Helv., 92, 163-170, 1999.

De Castro, P.: Nuove osservazioni sul livello ad Orbitoline in Campania, Boll. Soc. Nat. Napoli, 71, 103-135, 1963.

De Castro, P.: Mesozoic, in: 5th International Symposium on Fossil Algae, edited by: Barattolo, F., De Castro, P., and Parente, M., Field Trip Guide-Book, Giannini, Napoli, 21-38, 1991.

Dickson, J. A. D. and Coleman, M. L.: Changes in carbon and oxygen isotope composition during limestone diagenesis, Sedimentology, 27, 107-118, 1980.

Di Lucia M.: Il record dei cambiamenti globali nelle piattaforme del Cretacico medio dell'Appennino meridionale, $\mathrm{PhD}$ thesis, Università Federico II, Napoli, http://www.fedoa.unina.it/3342/, last access: January 2012, 2009.

Di Lucia M. and Parente M.: Carbon-isotope stratigraphy of upper Barremian-lower Albian shallow-water carbonates of southern Apennines (Italy): high-resolution correlation with deep-water reference sections, Rendiconti Online Soc. Geol. It., 2, 65-70, 2008.

Erba, E., Channell, J. E. T., Claps, M., Jones, C., Larson, R. L., Opdyke, B. N., Silva, I. P., Riva, A., Salvini, G., and Torricelli, S.: Integrated stratigraphy of the Cismon APTICORE (Southern Alps, Italy): a "reference section" for the Barremian-Aptian interval at low latitudes, J. Foramin. Res., 29, 371-391, 1999.

Erba, E., Bottini, C., Weissert, H. J., and Keller, C. E.: Calcareous Nannoplankton Response to Surface-Water Acidification around Oceanic Anoxic Event 1a, Science, 329, 428-432, 2010.

Ferreri, V., Weissert, H., D'Argenio B., and Buonocunto, F. P.: Carbon-isotope stratigraphy: a tool for basin to carbonate platform correlation: Terra Nova, 9, 57-61, 1997.

Föllmi, K. B.: A synchronous, middle Early Aptian age for the demise of the Helvetic Urgonian platform related to the unfolding oceanic anoxic event 1a ("Selli event"), Revue de Paléobiologie, Genève, 27, 2, 461-468, 2008.

Föllmi, K. B. and Gainon, F.: Demise of the northern Tethyan Urgonian carbonate platform and subsequent transition towards pelagic conditions: the sedimentary record of the Col de la Plaine Morte area, central Switzerland, Sediment. Geol., 205, 142-159, 2008.

Föllmi, K. B., Godet, A., Bodin, S., and Linder, P.: Interactions between environmental change and shallow water carbonate buildup along the northern Tethyan margin and their impact on the Early Cretaceous carbon isotope record, Paleoceanography, 21, 4211-4216, 2006.

Föllmi, K. B., Bodin, S., Godet, A., Linder, P., and van de Schootbrugge, B.: Unlocking paleo-environmental information from early Cretaceous shelf sediments in the Helvetic Alps: stratigraphy is the key!, Swiss J. Geosci., 100, 349-369, 2007.

Friedrich, O., Reichelt, K., Herrle, J. O., Lehmann, J., Pross, J., and Hemleben, C.: Formation of the Late Aptian Niveau Fallot black shales in the Vocontian Basin (SE France): evidence from foraminifera, palynomorphs, and stable isotopes, Mar. Micropa- leontol., 49, 65-85, 2003.

Frijia, G. and Parente, M.: Strontium isotope stratigraphy in the upper Cenomanian shallow-water carbonates of southern Apennines: Short-term perturbations of marine ${ }^{87} \mathrm{Sr} /{ }^{86} \mathrm{Sr}$ during the oceanic anoxic event 2, Palaeogeogr., Palaeocl., 261, 15-29, 2008.

Frijia, G., Parente, M., and Iannace, A.: Thermal maturity of the Southern Apenninic Platform Unit (Southern Italy): constraints from Rock-Eval Pyrolysis $\mathrm{T}_{\max }$ data. Atti Ticinensi di Scienze della Terra, serie speciale, 10, 95-98, 2005.

Ginsburg, R. N.: Landward movement of carbonate mud: new model for regressive cycles in carbonates, AAPG Bull., 55, 340, 1971.

Godet, A., Föllmi, K. B., Bodin, S., De Kaenel, E., Matera, V., Adatte, T., Arnaud-Vanneau, A., Arnaud, H., and Vermeulen, J.: A Late Barremian age for the onset of Urgonian-type facies in the Swiss Jura Mountains. Reply to the discussion by Conrad et al. 2011 on "Stratigraphic, sedimentological and palaeoenvironmental constraints on the rise of the Urgonian Platform in the western Swiss Jura" by Godet et al. (2010), Sedimentology, 57, 1088-1125, Sedimentology, doi:10.1111/j.13653091.2011.01276.x, 2011.

Gradstein, F. M., Ogg, J. G., and Smith, A. G.: A Geologic Time Scale 2004, Cambridge University Press, 589 pp., 2004.

Hallock, P.: Coral reefs, carbonate sediment, nutrients, and global change, in: Ancient reef ecosystems: their evolution, paleoecology and importance in earth history, edited by: Stanley, G. D., New York: Kluwer Academic/Plenum Publishers, 388-427, 2001.

Herrle, J. O., Kößler, P., Friedrich, O., Erlenkeuser, H., and Hemleben, C.: High-resolution carbon isotope records of the Aptian to lower Albian from SE France and the Mazagan Plateau (DSDP Site 545), A stratigraphic tool for paleoceanographic and paleobiologic reconstruction, Earth Planet. Sci. Lett., 218, 149-161, 2004.

Hillgärtner, H., van Buchem, F. S. P., Gaumet, F., Razin, P., Pittet, B., Grötsch, J., and Droste, H. J.: The Early Cretaceous carbonate margin of the eastern Arabian platform (northern Oman): Sedimentology, sequence stratigraphy and environmental change, J. Sed. Res., 73, 756-773, 2003.

Huck, S., Rameil, N., Korbar, T., Heimhofer, U., Wieczorek, T. D., and Immenhauser, A.: Latitudinally different responses of Tethyan shoal-water carbonate systems to the Early Aptian oceanic anoxic event (OAE 1a), Sedimentology, 57, 1585-1614, 2010.

Huck, S., Heimhofer, U., Rameil, N., Bodin, S., and Immenhauser, A.: Strontium and carbon-isotope chronostratigraphy of Barremian-Aptian shoal-water carbonates: Northern Tethyan platform drowning predates OAE 1a, Earth Planet. Sc. Lett., 304, 547-558, doi:10.1016/j.eps1.2011.02.031, 2011.

Husinec, A. and Sokač, B.: Early Cretaceous benthic associations (foraminifera and calcareous algae) of a shallow tropical-water platform environment (Mljet Island, southern Croatia), Cret. Res., 27, 418-441, 2006.

Immenhauser, A., Schlager, W., Burns, S. J., Scott, R. W., Geel, T., Lehmann, J., van der Gaast, S., and Bolder-Schrijver, L. J. A.: Late Aptian to Late Albian sea level fluctuations constrained by geochemical and biological evidence (Nahr Umr Formation, Oman), J. Sed. Res., 69, 434-446, 1999. 
Immenhauser, A., Hillgärtner, H., and van Bentum, E.: Microbialforaminiferal episodes in the Early Aptian of the southern Tethyan margin: ecological significance and possible relation to oceanic anoxic event 1a, Sedimentology, 52, 77-99, 2005.

Immenhauser, A., Holmden, C., and Patterson, W. P.: Interpreting the Carbon-Isotope Record of Ancient Shallow Epeiric Seas: Lessons from the Recent, in: Dynamics of Epeiric Seas: Geological Association of Canada Special Publication, edited by: Pratt, B. R. and Holmden, C., 48, 135-174, 2008.

Jenkyns, H. C.: Carbon-isotope stratigraphy and paleoceanographic significance of the Lower Cretaceous shallow-water carbonates of Resolution Guyot, mid-Pacific Mountains, in: Proceedings of the Ocean Drilling Program, Scientific Results, 143, edited by: Winterer, E. L., Sager, W. W., Firth, J. V., and Sinton, J. M., Ocean Drilling Program, College Station, TX, 99-104, 1995.

Joachimsky, M.: Subaerial exposure and deposition of shallowing upward sequences: evidence from stable isotopes of Purbeckian peritidal carbonates (basal Cretaceous), Swiss and French Jura Mountains, Sedimentology, 41, 805-824, 2004.

Jones, B., Simmons, M., and Whittaker, J.: Chronostratigraphic and paleoenvironmental significance of agglutinated and associated larger benthonic foraminifera from the Lower to "Middle" Cretaceous of the Middle east, in: Proceeding of the Sixth International Workshop on Agglutinated Foraminifera, edited by: Bubik, M., and Kaminski, M. A., Grzybowski Found. Spec. Publ., 8, 229-235, 2004.

Larson, R. L. and Erba, E.: Onset of the mid-Cretaceous greenhouse in the Barremian-Aptian: Igneous events and the biological, sedimentary, and geochemical responses, Paleoceanography, 14, 663-678, 1999.

Li, Y. X., Bralower, T. J., Montañez, I. P., Osleger, D. A., Arthur, M. A., Bice, D. M., Herbert, T. D., Erba, E., and Premoli Silva, I.: Toward an orbital chronology for the early Aptian Oceanic Anoxic Event (OAE1a, 120 Ma), Earth Planet. Sc. Lett., 271, 88-100, 2008.

Linder, P., Gigandet, J., Hüsser, J. L., Gainon, F., and Föllmi, K. B.: The early Aptian Grünten Member: description of a new lithostratigraphic unit of the Helvetic Garschella Formation, Eclogae Geol. Helv., 99, 327-341, 2006.

Lohmann, K. C.: Geochemical patterns of meteoric diagenetic systems and their application to studies of paleokarst, in: Paleokarst, edited by: James, N. P. and Choquette, P. W., Springer, Berlin, 58-80, 1988.

Malinverno, A., Erba, E., and Herbert, T. D.: Orbital tuning as an inverse problem: Chronology of the early Aptian oceanic anoxic event 1a (Selli Level) in the Cismon APTICORE, Paleoceanography, 25, PA2203, doi:10.1029/2009PA001769, 2010.

Marshall, J. D.: Climatic and oceanographic isotopic signals from the carbonate rock record and their preservation, Geol. Mag., 129, 143-160, 1992.

Masse, J. P., El Albani, A., and Erlenkeuser, H.: Stratigraphie isotopique $\left(\delta^{13} \mathrm{C}\right)$ de l'Aptien inférieur de Provence (SE France): Application aux corrélations plate-forme/bassin, Eclogae Geol. Helv., 92, 259-263, 1999.

McArthur, J. M., Howarth, R. J., and Bailey, T. R.: Strontium Isotope Stratigraphy: LOWESS Version 3: best fit to the marine Sr-Isotope Curve for 0-509 Ma and accompanying look-up table for deriving numerical age, J. Geol., 109, 155-170, 2001.

Méhay, S., Keller, C. E., Bernasconi, S. M., Weissert, H., Erba, E.,
Bottini, C., and Hochuli, P. A.: A volcanic $\mathrm{CO}_{2}$ pulse triggered the Cretaceous Oceanic Anoxic Event 1a and a biocalcification crisis, Geology, 37, 819-822, 2009.

Menegatti, A. P., Weissert, H., Brown, R. S., Tyson, R. V., Farrimond, P., Strasser, A., and Caron, M.: High-resolution $\delta^{13} \mathrm{C}$ stratigraphy through the early Aptian "Livello Selli" of the Alpine Tethys, Paleoceanography, 13, 530-545, 1998.

Millán, M. I., Weissert, H. J., Owen, H., Fernández-Mendiola, P. A., and Garcia-Mondéjar, J.: The Madotz Urgonian platform (Aralar, northern Spain): Paleoecological changes in response to Early Aptian global environmental events, Palaeogeogr., Palaeocl., 312, 167-180, doi:10.1016/j.palaeo.2011.10.005, 2011.

Parente, M., Frijia, G., and Di Lucia, M.: Carbon-isotope stratigraphy of Cenomanian- Turonian platform carbonates from southern Apennines (Italy): a chemostratigraphic approach to the problem of correlation between shallow-water and deep-water successions, J. Geol. Soc. Lond., 164, 609-620, 2007.

Patterson, W. P. and Walter, L. M.: Depletion of ${ }^{13} \mathrm{C}$ in seawater $\sum \mathrm{CO}_{2}$ on modern carbonate platforms: significance for the carbon isotopic record of carbonates, Geology, 22, 885-888, 1994.

Pittet, B., van Buchem, F. S. P., Hillgärtner, H., Razin, P., Grötsch, J., and Droste, H. J.: Ecological succession, palaeoenvironmental change, and depositional sequences of Barremian - Aptian shallow-water carbonates in northern Oman, Sedimentology, 49, 555-581, 2002.

Pratt, B. R. and James, N. P.: The St George Group (Lower Ordovician) of western Newfoundland: tidal flat island model for carbonate sedimentation in shallow epeiric seas, Sedimentology, 33, 313-343, 1986.

Prokoph, A., Shields, G. A., and Veizer, J.: Compilation and timeseries analysis of a marine carbonate $\delta^{18} \mathrm{O}, \delta^{13} \mathrm{C},{ }^{87} \mathrm{Sr} /{ }^{86} \mathrm{Sr}$ and $\delta^{34} \mathrm{~S}$ database through Earth history, Earth Sci. Rev., 87, 113133, 2008.

Raspini, A.: Microfacies analysis of shallow water carbonates and evidence of hierarchically organized cycles, Aptian of Monte Tobenna, Southern Apennines, Italy, Cret. Res., 19, 197-223, 1998.

Raspini, A.: Stacking pattern of cyclic carbonate platform strata: Lower Cretaceous of southern Apennines, Italy, J. Geol. Soc. Lond., 158, 353-366, 2001.

Raspini, A.: Shallow water carbonate platforms (Late Aptian, Southern Apennines) in the context of supraregional to global changes, Solid Earth Discuss., 3, 901-942, doi:10.5194/sed-3901-2011, 2011.

Sadler, P. M.: The expected duration of upward-shallowing peritidal carbonate cycles and their terminal hiatuses, Geol. Soc. Am. Bull., 106, 791-802, 1994.

Sartoni, S. and Crescenti, U.: Ricerche biostratigrafiche nel Mesozoico dell'Appennino meridionale, Giornale di Geologia, 29, 161-293, 1962.

Schenk, K.: Die Drusberg- und Schrattenkalk-Formation (Unterkreide) im Helvetikum des Berner Oberlandes, Unpublished $\mathrm{PhD}$ Thesis, University of Berne, 1992.

Schroeder, R., Schenk, K., Cherchi, A., and Schwizer, B.: Sur la présence de grands foraminifères d'âge aptien supérieur dans l'Urgonien de la Nappe du Wildhorn (Suisse centrale). Note préliminaire, Revue de Paléobiologie, 26, 665-669, 2007.

Schroeder, R., van Buchem, F. S. P., Cherchi, A., Baghbani, D., Vincent, B., Immenhauser, A., and Granier, B.: Revised orbitolinid 
biostratigraphic zonation for the Barremian - Aptian of the eastern Arabian Plate and implications for regional stratigraphic correlations, GeoArabia Spec. P., 4, 1, 49-96, 2010.

Simmons, M. D.: Micropalaeontological biozonation of the Kahmah Group (Early Cretaceous), Central Oman Mountains, in: Micropalaeontology and Hydrocarbon Exploration in the Middle East, edited by: Simmons, M. D., Chapman and Hall, London, 177-219, 1994.

Skelton, P. W. and Gili, E.: Rudists and carbonate platforms in the Aptian: a case study on biotic interactions with ocean chemistry and climate, Sedimentology, 59, 81-117, doi:10.1111/j.13653091.2011.01292.x, 2011.

Strasser, A.: Lagoonal-peritidal sequences in carbonate environments: autocyclic and allocyclic processes, in: Cycles and Events in Stratigraphy, edited by: Einsele, G., Ricken, W., and Seilacher, A., Springer, Berlin, 709-721, 1991.

Strasser, A., Pittet, B., Hillgärtner, H., and Pasquier, J.-B.: Depositional sequences in shallow carbonate-dominated sedimentary systems: concepts for a high-resolution analysis, Sed. Geol., 128, 201-221, 1999.

Strasser, A., Hillgärtner, H., Hug, W., and Pittet, B.: Third-order depositional sequences reflecting Milankovitch cyclicity, Terra Nova, 12, 303-311, 2000.

Strasser, A., Védrine, S., and Stienne, N.: Rate and synchronicity of environmental changes on a shallow carbonate platform (Late Oxfordian, Swiss Jura Mountains), Sedimentology, 59, 185-211, doi:10.1111/j.1365-3091.2011.01236.x, 2011.

Swart, P. K.: Is there really a mixing-zone stable carbon and oxygen isotope signal? Abstracts, 28th IAS Meeting of Sedimentology 2011, Zaragoza, Spain, 2011.

Swart, P. K., Reijmer, J. J. G., and Otto, R.: A re-evaluation of facies on Great Bahama Bank II: variations in the $\delta^{13} \mathrm{C}, \delta^{18} \mathrm{O}$ and mineralogy of surface sediments, Int. Assoc. Sedimentol. Spec. Publ., 41, 47-59, 2009.

Tešović, B. C., Glumac, B., and Bucković, D.: Integrated biostratigraphy and carbon isotope stratigraphy of the Lower Cretaceous (Barremian to Albian) Adriatic-Dinaridic carbonate platform deposits in Istria, Croatia, Cret. Res., 32, 301-324, 2011.

Tejada, M. L. G., Suzuki, K., Kuroda, J., Coccioni, R., Mahoney, J. J., Ohkouchi, N., Sakamoto, T., and Tatsumi, Y.: Ontong Java Plateau eruption as a trigger for the early Aptian oceanic anoxic event, Geology, 37, 855-858, 2009.
Tipper, J. C.: Modeling carbonate platform sedimentation - Lag comes naturally, Geology, 25, 495-498, 1997.

Vahrenkamp, V. C.: Chemostratigraphy of the Lower Cretaceous Shu'aiba Formation: A $\delta^{13} \mathrm{C}$ reference profile for the Aptian Stage from the southern Neo-Tethys Ocean, GeoArabia Spec. Publ., 4, 1, 107-137, 2010.

Velić, I.: Stratigraphy and palaeobiogeography of Mesozoic benthic foraminifera of the Karst Dinarides (SE Europa), Geologia Croatica, 60, 1-113, 2007.

Vilas, L., Masse, J. P., and Arias, C.: Orbitolina episodes in carbonate platform evolution: the early Aptian model from SE Spain, Palaeogeogr., Palaeocl., 119, 35-45, 1995.

Wagner, P. D.: Geochemical stratigraphy and porosity controls in Cretaceous carbonates near the Oman Mountains, in: The Geology and Tectonics of the Oman Region, edited by: Robertson, A. H. F., Searle, M. P., and Ries, A. C., Geol. Soc. Spec. Publ., 49, 127-137,1990.

Weber, J. N. and Woodhead, P. M. J.: Factors affecting the carbon and oxygen isotopic composition of marine carbonate sedimentsII. Heron Island, Great Barrier Reef, Australia, Geochim. Cosmochim. Ac., 33, 19-38, 1969.

Weissert, $\mathrm{H}$. and Erba, E.: Volcanism, $\mathrm{CO}_{2}$ and paleoclimate: a Late Jurassic-Early Cretaceous oxygen isotope record, J. Geol. Soc. Lond., 161, 695-702, 2004.

Wissler, L., Funk, H., and Weissert, H.: Response of Early Cretaceous carbonate platforms to changes in atmospheric carbon dioxide levels, Palaeogeogr. Palaeocl., 200, 187-205, 2003.

Wissler, L., Weissert, H., Buonocunto, F. P., Ferreri, V., and D'Argenio, B.: Calibration of the Early Cretaceous time scale: a combined chemostratigraphic and cyclostratigraphic approach to the Barremian-Aptian interval Campania Apennines and southern Alps (Italy), in: Cyclostratigraphy, approaches and case histories, edited by: D'Argenio, B., Fischer, A. G., Premoli Silva, I., Weissert, H., and Ferreri, V., 2004, SEPM Spec. P., 81, 123-134, 2004.

Witt, W. and Gökdağ, H.: Orbitolinid biostratigraphy of the Shu'aiba Formation (Aptian), Oman - implications for reservoir development, in: Micropalaeontology and Hydrocarbon Exploration in the Middle East, edited by: Simmons, M. D., Chapman and Hall, London, 241-271, 1994. 